\title{
PAISAGEM E CONFIGURAÇÃO ESPACIAL NO RIO DE JANEIRO: OS ESPAÇOS LIVRES URBANOS NO SÉCULO 19*
}

MARIO CENIQUEL

Arquiteto, mestré e doutourado FAUUSP. Professor de projeto de edificios e paisagismo da Faculdade de Arquitetura e Urbanismo da Universidade Federal do Rio de Janeiro. 


\section{RESUMO}

tradição paisagística carioca alicerçada, nos primórdios da cidade, em algumas iniciativas urbanísticas e ambientais ainda no século 18, tanto no período dos governadores como, particularmente, no período dos vice-reis.

Este proceso, assim iniciado, irá se desenvolver ao longo do prolífico século 19 - desde Grandjean de Montigny (neoclássico) até Glaziou (romântico), e irá cristalizar-se, no século 20, inicialmente na grande (e polêmica) obra do prefeito Francisco Pereira Passos e, posteriormente, no trabalho de Roberto Burle Marx.

Focaliza-se a figura do engenheiro Auguste Marie François Claziou (18331906), na medida em que consideramos sua obra, em termos paisagísticos, a mais marcante do século 19 em nosso país, que, por outro lado, origina as primeiras discussões urbanísticas conseqüentes sobre o Rio de Janeiro, sobretudo no que se refere ao projeto e gerenciamento dos espaços livres urbanos da cidade, criando, assim, as condições propícias para as grandes intervenções urbanísticas na cidade no século 20 .

\section{ABSTRACT}

G enerally, the main subject is related to the thesis that there is a landscape design tradition in Rio, built on important urbanistic and environmental movements, held on the city's early history, back in the eighteenth century, during both the governor's and the vice-rey's colonial periods.

This process, begun as described, was later on developed during the prodigious nineteenth century, since the Architect Grandjean de Montigny (neo-classicist) until Glaziou (romanticist). It has crystallized out in the twentieth century, firstly in the outstanding and polemic administration of City Major Francisco Pereira Passos ( 1902-1906) and, lately, in the career of Roberto Burle Marx.

The content focuses on french Engineer Auguste Marie François Glaziou (1833-1906), since we consider his work, in the landscape field, the most important one of the nineteenth century In Brazil. It iniciates the firtt consequent discussions about the city of Rio de Janeiro, mainly related to the urban open escapes design and management, creating, as a consequence, the proper background for the escale urbanistic interventions in city, during the twentieth century. 


\section{OS ESPAÇOS LIVRES NA EVOLUÇÃO DA CIDADE DO RIO DE JANEIRO}

\section{O RIO LUSO-BRASILEIRO}

Sem dúvida boa parte da história urbanística do Brasil está profundamente associada à evolução da cidade do Rio de Janeiro, particularmente no período em que foi capital do país, desce a vinda da Família Real portuguesa até a transferência do Distrito Federal para Brasília.

Este processo de destaque nacional, originado a partir da decadência da mineração nas Minas Gerais, que se cristaliza, posteriormente, com sua elevação à condição de capital da colônia e sede do vice-reinado em 1763, atinge seu ponto mais alto com a transferência da corte portuguesa para o Brasil, e sua conseqüente transformação em Reino Unido, em 1815.

Aliados a estes fatores, a abertura dos portos, decretada anteriormente pelo príncipe regente, e os tratados assinados com a Inglaterra em 1810, estendidos às demais nações em 1822, que beneficiavam particularmente os países mais fortemente impulsionados pelos efeitos da Revolução Industrial - com destaque para Inglaterra -, acabam por construir uma estrutura de integração (dependente) do Brasil com o mercado mundial, cabendo ao Rio de Janeiro, dentro desse esquema, um destaque estratégico evidente. (Benchimol, 1990)

Curioso é observar que desde sua fundação no morro do Castelo - após a abortada tentativa no Morro Cara de Cão - e de sua descida para a várzea, em fins do século 16, a cidade do Rio de Janeiro manteve até meados do século 18 sua feição de vilarejo, sem grandes modificações, balizado pelos quatro morros que definiriam, seu limite virtual, até o século 20: Castelo, Santo Antônio, São Bento e Conceição.

Porém, será na segunda metade do século 18, devido aos fatores sumariamente colocados antes, que o Rio de Janeiro adquire um 
impulso de crescimento de grande magnitude e velocidade, nunca visto nos seus anteriores dois séculos de existência, que além de mudar sensivelmente a estruturação espacial da cidade, como iria criar a semente das grandes intervenções urbanísticas em nosso século.

Tendo seu perfil urbano nitidamente caracterizado pela forma de ocupação do lote, o Rio de Janeiro no período luso-brasileiro - assim como boa parte das vilas e cidades brasileiras - apresentava, até século 18 (...)"ruas de aspecto uniforme, com casas térreas e sobrados construídos sobre o alinhamento das vias públicas e sobre os limites laterais dos terrenos" (...). (Benchimol, 1990)

Esta uniformidade na estruturação espacial da cidade, decorrente do adensamento horizontal do espaço construído, é claramente percebido em gravuras e estampas dos pintores viajantes da época, onde é comum ver paisagens urbanas do rio colonial, mostrando suas ruas estreitas (mais ainda pelo trânsito de homens, mercadorias e veículos, além de atividades comerciais), sem meio fio, dada a inexistência de passeio para pedestres.

Como descreve Thomas Ewbank, industrial inglês residente em Nova York, autor de " $A$ vida do Brasil ou diário de uma visita ao país do cacau e das palmeiras", num relato extremamente valioso sobre a cidade na primeira metade do século 19:

(...) "A maioria das ruas do Rio se cruza em ângulo reto, mas encontram-se algumas que não seguem a direção da bússola, circunstância devido às montanhas que as separam e ao contomo irregular das praias da baía. São estreitas... O perfil transversal das ruas obedece ao modelo antigo: o calçamento se abaixa de ambos os lados, desde a frente das casas até o meio da rua... e os carros, quando se cruzam, quase que tocam nas casas de um e outro lado. Pela mesma razão, não se permite escada saliente ou qualquer coisa que sobressaia na fachada" (...). (Ewbank, 1873) 

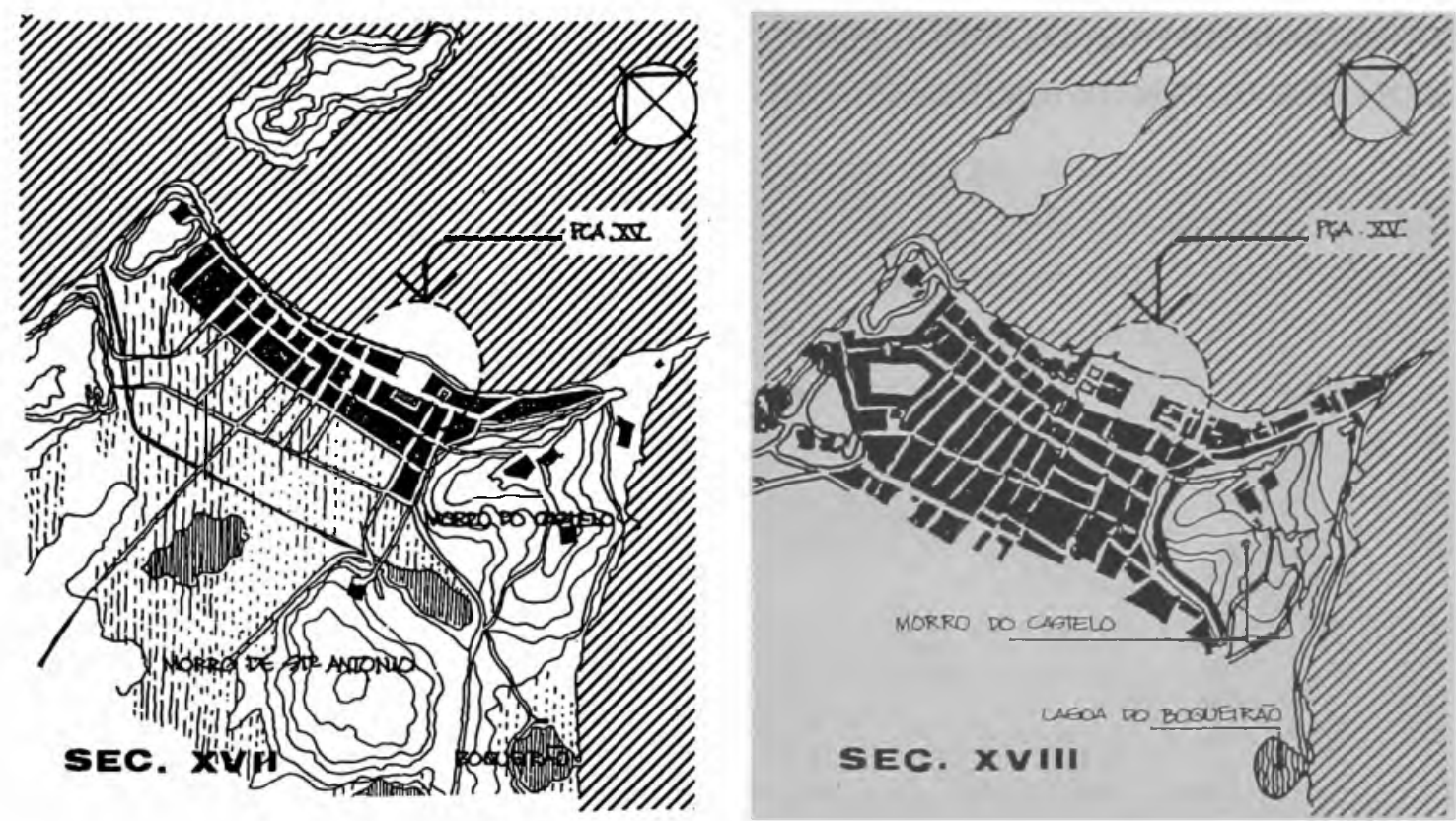

Figura 1 - O largo do Paço (atual praça XV de Novembro) no contexto da evolução do centro do Rio de Janeiro nos séculos 17 e 18 (Canabrava, 1965).

Em linhas gerais, as narrativas dos viajantes refletem, simultaneamente, um similar sentimento de deslumbramento diante da vista geral da cidade, tanto no que se refere à exuberância da paisagem natural, quanto à imponência da posição da massa edificada em relação a esta, pontuada pelas agulhas das numerosas igrejas que nela se inseriam, com a aversão "suscitada pela paisagem material e humana" De fato, a presença dos marcos religiosos mencionados são de importância estratégica para entender a formação de configurações espaciais historicamente significantes do Rio-Colônia. (Sisson, 1986)

Uma observação superficial de gravuras e desenhos do período assinalado - o luso-brasileiro - evidencia a dominância desses marcos, destacados nitidamente do casario (altura e cor), e criando uma "ruptura" clara (adros, largos, etc.) na uniforme malha constituída pelas ruas.

Com freqüência os marcos religiosos constituíam referências espaciais da cidade e deram origem a denominações de logradouros, distritos e acidentes naturais. Através deles, articulavam-se os caminhos, o território e a paisagem urbana e, 
conseqüentemente, o próprio espaço urbano, que, ao fundir-se com o espaço sacro, resultava numa continuidade entre ambos.

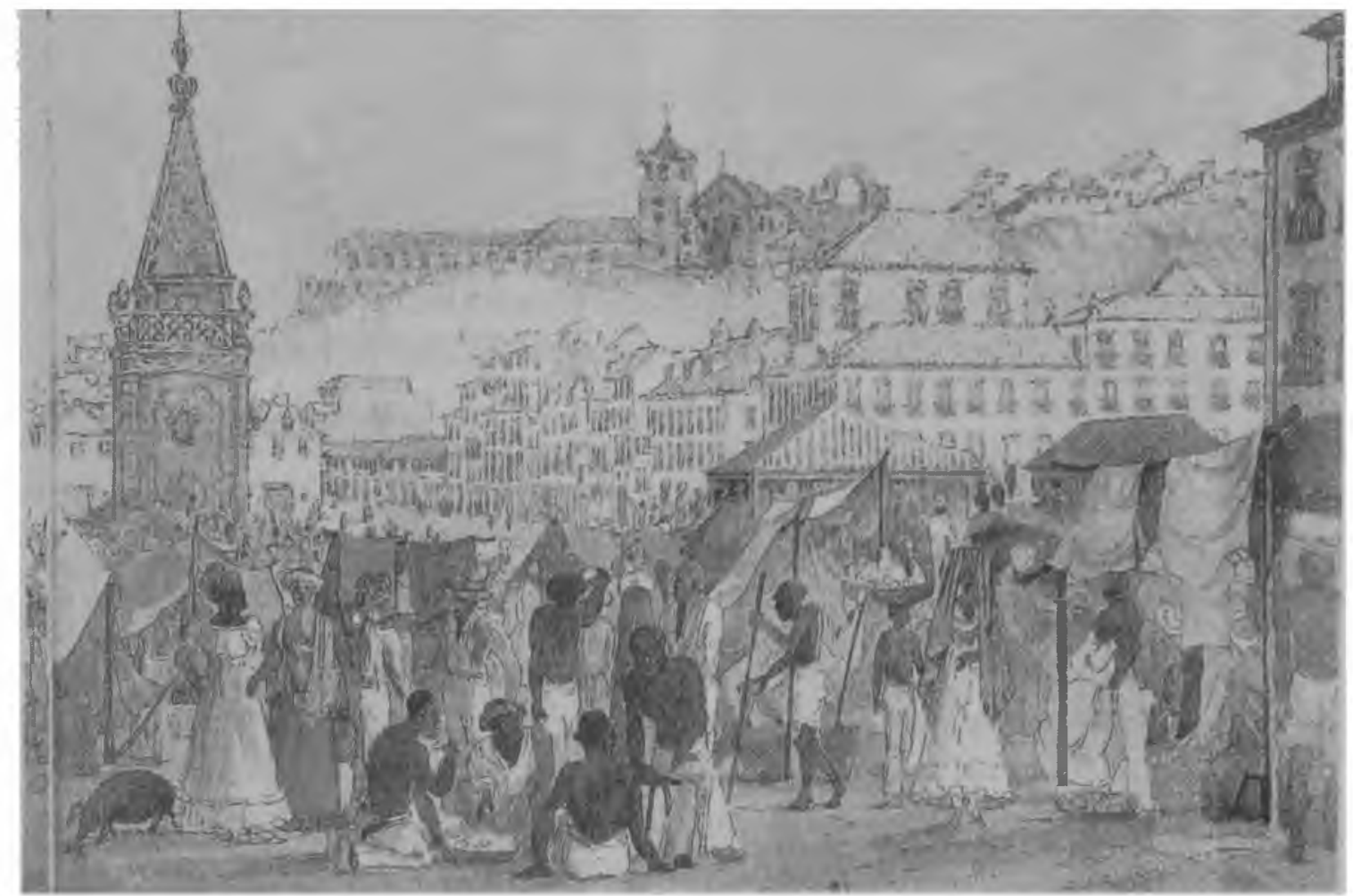

Figura 2 - Vista do Mercado do largo do Paço (atual praça XV de Novembro), segundo trecho de aquarela sobre papel de William Smith, assinado e datado em 1832.

É neste contexto que deve ser entendido um dos espaços livres urbanos mais tradicionais do Rio de Janeiro: a atual praça XV de Novembro (ex-largo do Paço, largo do Carmo, terreiro da Polé, terreiro de Nossa Sra. do Carmo, terreiro de Nossa Sra. do Ó, etc., entre outros).

Este espaço livre urbano originou-se inicialmente como um nó, pela confluência de caminhos, estabelecendo uma continuidade entre as duas mais importantes vias urbanas coloniais (a rua da Misericórdia e a rua Direita) e pela presença de marcos característicos, inicialmente religiosos (as prestigiosas ordens das carmelitas e dos terreiros do (armo) e posteriormente denotativos das diferentes instâncias do poder, com seu adensamento no 
decorrer dos anos (caso dos governadores, palácio dos vice-reis, paço real, câmara e cadeira, etc.).

Decorrente de uma configuração quase que espontânea, pela ausência de uma formulação urbanística prévia, o largo do Paço apresenta nos primeiros anos do século 19, características espaciais que em muito o aproximam, no seu confronto com a inserção urbana, da praça do comércio (o grandioso terreiro do paço) da Lisboa pombolina. "suprema expressão simbólica do urbanismo tradicional da Europa do domínio marítimo de uma grande nação".

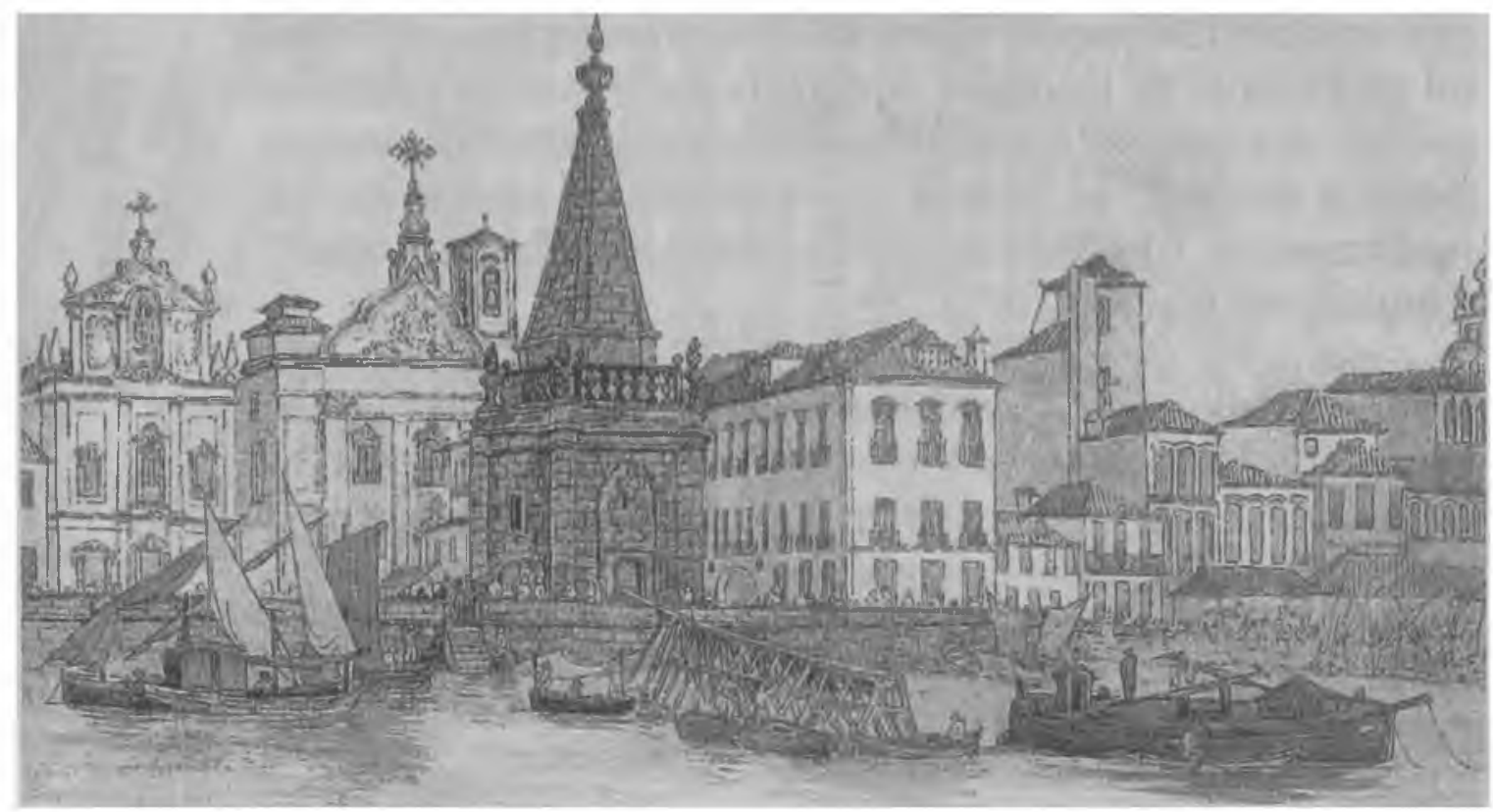

Figura 3 - Trecho de vista geral do largo do Paço tomada do mar, localizada no chafariz do Mestre Valentim e a rampa de desembarque do cais, segundo aquarela sobre papel, assinada e datada em 1832 de autoria de William Smith.

A importância da referência ao largo do Paço (atual praça XV de Novembro) reside no papel que como espaço livre urbano, tanto em termos de sua origem como de sua destinação (no geral reservada a atos oficiais de comemoração), desempenhou na caracterização urbana da cidade: é um exemplo único, singular, embora, tipologicamente, bem definido. (Ceniquel, 1993) 
A partir destas considerações, pode ser entendida a notória relevância do projeto execução do passeio público do mestre Valentim (1779-1783) durante o vice-reinado de $D$. Luis de Vasconcellos (1779-1790). De fato seu ineditismo não reside simplesmente na sua condição de jardim, o que por si já o colocaria numa posição de destaque na ambiência típica do Rio colonial, como também por representar um espaço livre de uso público, que o coloca numa posição de pioneirismo absoluto em toda América Latina.

Em outros termos, o conceito de jardim não era novo: desde as mais antigas civilizações - em todos os cantos do mundo existiu o conceito, ora com conotações religiosas e/ou filosóficas, ora com conotações utilitárias e/ou contemplativas. Nesse rol se incluem os lendários jardins da Babilônia, os jardins e parques dos castelos europeus ou chineses, o jardim doméstico grego e romano, os jardins dos monastérios medievais, os renascentistas, o jardim francês (Versailles), italiano (as "Villas") e inglês, etc. (Laurie, 1976)

Porém, o conceito de "parque de uso público", é um conceito próprio da Era moderna, e surge na Europa, a partir da abertura à população dos grandes jardins dos palácios e mansões da nobreza, e se incorpora definitivamente à estrutura urbana com a eclosão da Revolução Industrial, particularmente na Inglaterra, ainda no século 17, e na França, nos séculos 18 e, particularmente, no século 19.

O Rio de Janeiro, no século 18, apresentava uma área urbana bem exígüa que, além dos seus limites naturais (os morros e o mar), era contornada por uma muralha de fortificação construída por um oficial de engenharía vindo de Lisboa (general Massé). (Oliveira Reis, 1988)

E curioso observar que, no campo ambiental, a primeira idéia de proteção às matas e jardins, de que se tem conhecimento na cidade do Rio de Janeiro, data de 1740, ainda no período lusobrasileiro. 


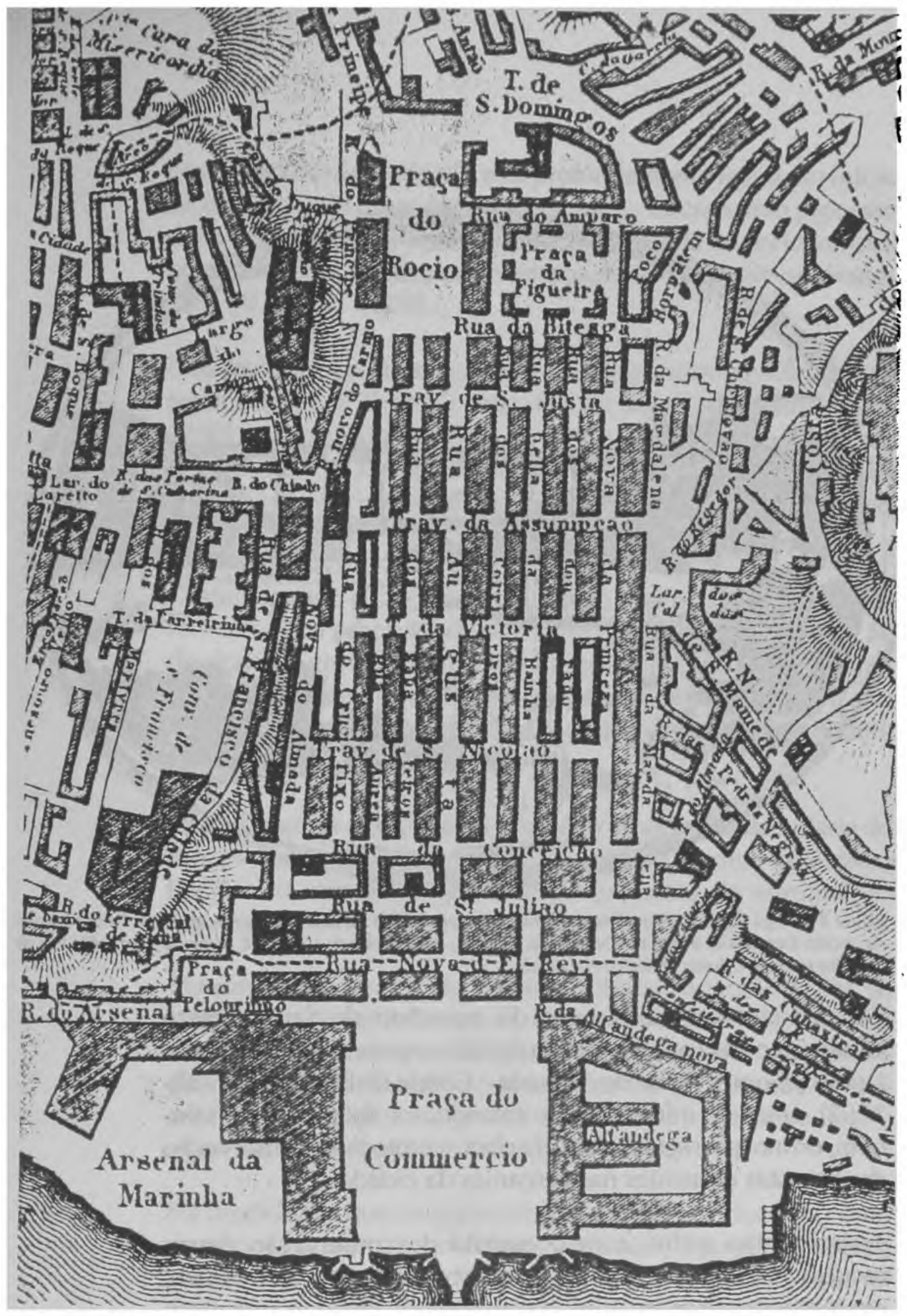

Figura 4 - Planta do Centro de Lisboa datada de 1833: pormenor da parte baixa da cidade (...) À beira do Tejo fica a "Praça do Commercio", seguindo-se a ela um traçado viário regular recobrindo a parte baixa da cidade, delimitada pelas colinas de São Jorge, à direita, e de São Franscisco, à esquerda"... (Sisson, 1986). 


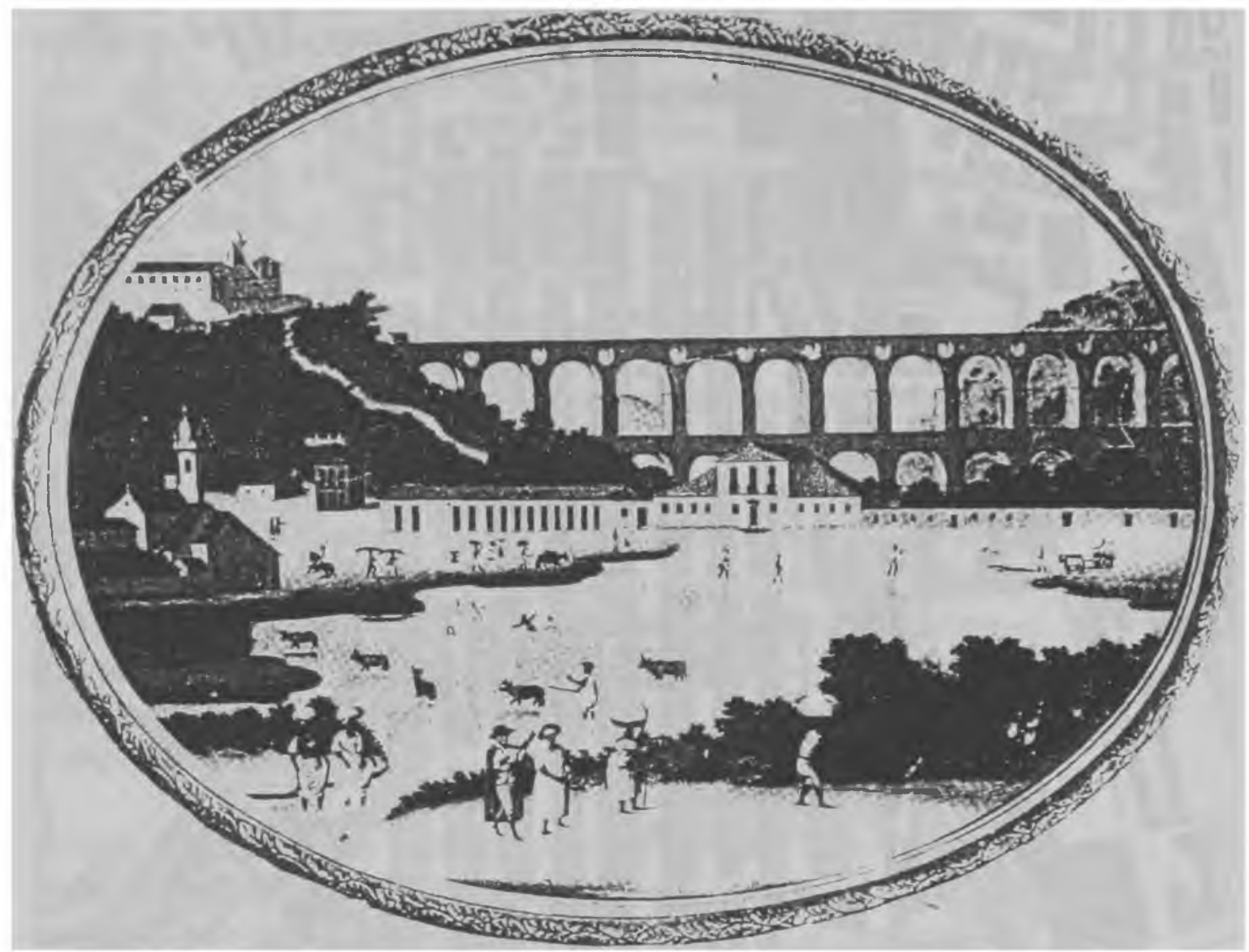

Figura 5 - Antiga lagoa do Boqueirão monstrando o aqueduto da Carioca e Convento de Santa Teresa (no alto do morro à esquerda) e igreja de Nossa Sra. da Lapa, em meados do século 18, segundo óleo sobre tela de Leandro Joaquim (Museu Histórico Nacional).

Por ocasião da reconstrução do aqueduto de Santa Tereza (atuais arcos da Lapa) na gestão do último governador do Rio de Janeiro, Gomes Freire de Andrade - Conde de Bobadela (17331762), antes do início do vice-reinado, foi determinado, também, no ato que regulava aquela obra, a proteção e conservação das florestas existentes nas cercanias da cidade.

Teriam então assim, com o espírito de conservação desses recursos naturais, surgido os primeiros elementos que viriam, em tempos mais avançados, a constituir os alicerces que serviriam de base à criação de um órgão oficial com as incumbências de garantir a sua permanente manutenção e franquia ao público. 
O período do vice-reinado está profundamente ligado ao início de uma série de obras que, em boa parte, iniciariam o processo de modernização e expansão da cidade, ainda no período lusobrasileiro, num relativo curto espaço de tempo, entre os séculos 18 e 19 (1763 - 1808).

Dos sete vice-reis que ocuparam o cargo, sem dúvida, o mais prolífico foi o $4^{\circ}$ deles, D. Luiz de Vasconcellos e Souza (17791790), que aliado ao talento do mestre Valentim da Fonseca e Silva (1745-1813), empreenderam as primeiras obras de cunho urbanístico na cidade do Rio de Janeiro, a saber: $O$ Jardim do Passeio Público.

O alargamento e calçamento do largo do Paço (antigo terreiro da Polé, atual praça $X V$ de novembro), a respectiva construção do chafariz, em substituição do antigo construído pelo governador Gomes Freire de Andrade, projeto do mestre Valentim, e a construção do cais ao longo da praça até a ponta do calabouço. (Oliveira Reis, 1988)

Se analisarmos a história da evolução urbanística da cidade do Rio de Janeiro, podemos ver que foi um jardim (o Passeio Público) o marco inaugural de um processo de estruturação espacial urbana.

Outrossim, os jardins do Passeio Público, estabelece por si, como dizíamos anteriormente, um marco notável no estabelecimento da saga de uma tradição paisagística carioca, no que se refere ao tratamento de espaços livres verdes urbanos de uso público e o papel da gestão administrativa pública como agenciadora de tais intervenções.

Na medida em que considerarmos a gestão dos vice-reis como precursora dos atuais governos municipais, o papel do mestre Valentim deve ser inserido na busca do estabelecimento de tal tradição à luz do papel dos profissionais de competência específica, à serviço de tais administrações. 
Assim mesmo, esta ação profissional, que a partir de mestre Valentim - e por mais de 200 anos - se prolonga até nossos dias no Rio de Janeiro (através da atuação da Fundação Parques e Jardins ) atravessa três séculos (século 18 ao século 20) gerando modelos de agenciamento de espaços verdes públicos, que foram aplicados no Brasil todo, em grande parte como indicativos de gestão "modernizante"

Por outro lado, o projeto do Passeio Público do mestre Valentim evidencia uma atitude diante do meio ambiente natural, cuja intenção principal era criar um gênero de jardim condicionado às nossas necessidades, particularmente no que se refere ao uso da vegetação para criação de grandes áreas de sombra, atitude esta, totalmente inédita em termos urbanís-ticos, na ocasião.

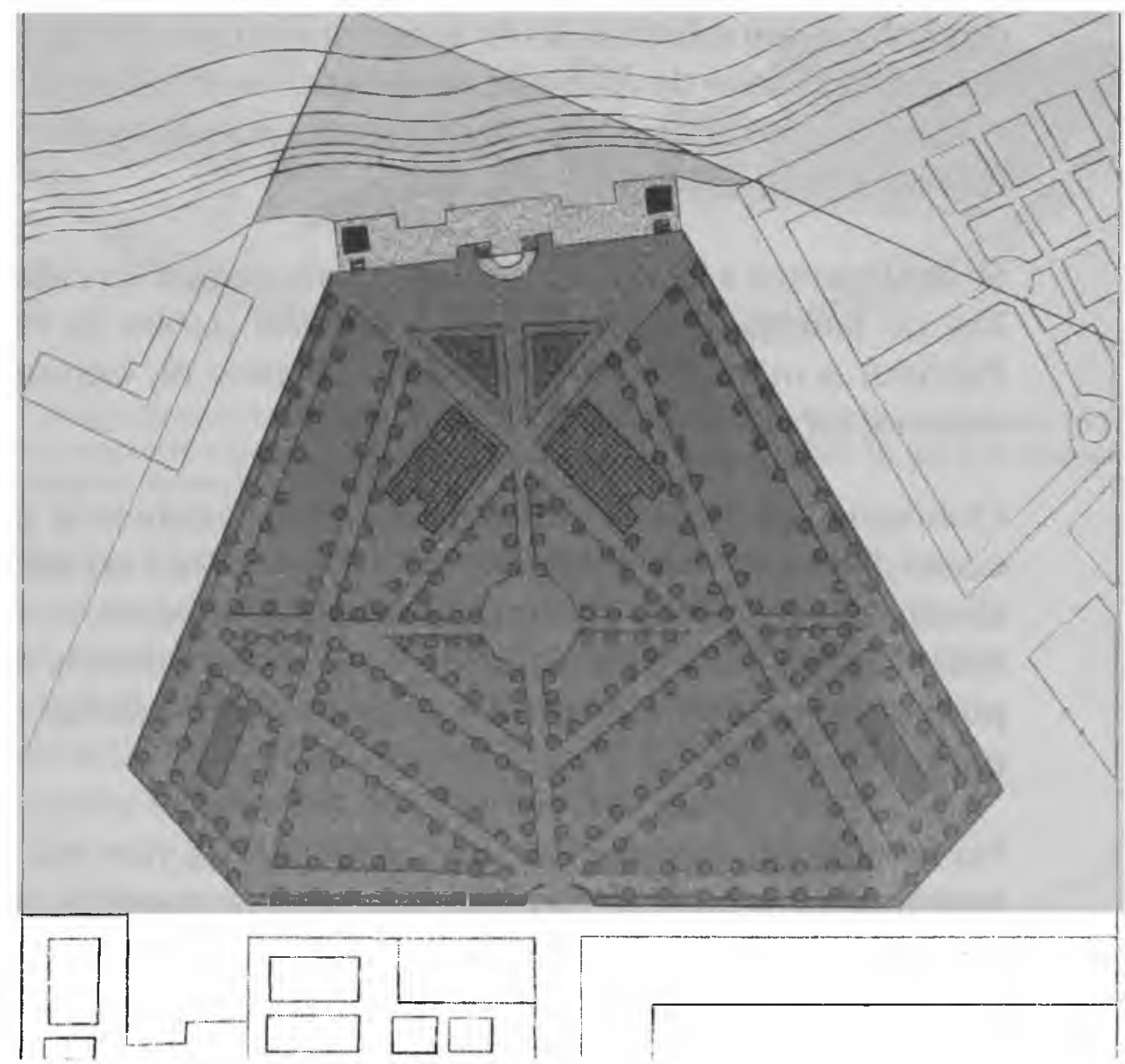

Figura 6 - O Passeio Público segundo a planta régia de 1812, monstrando o traçado original do Mestre Valentim. Extraida da planta produzida pelo projeto Quapá. Desenho: Luiz Maurfcio 


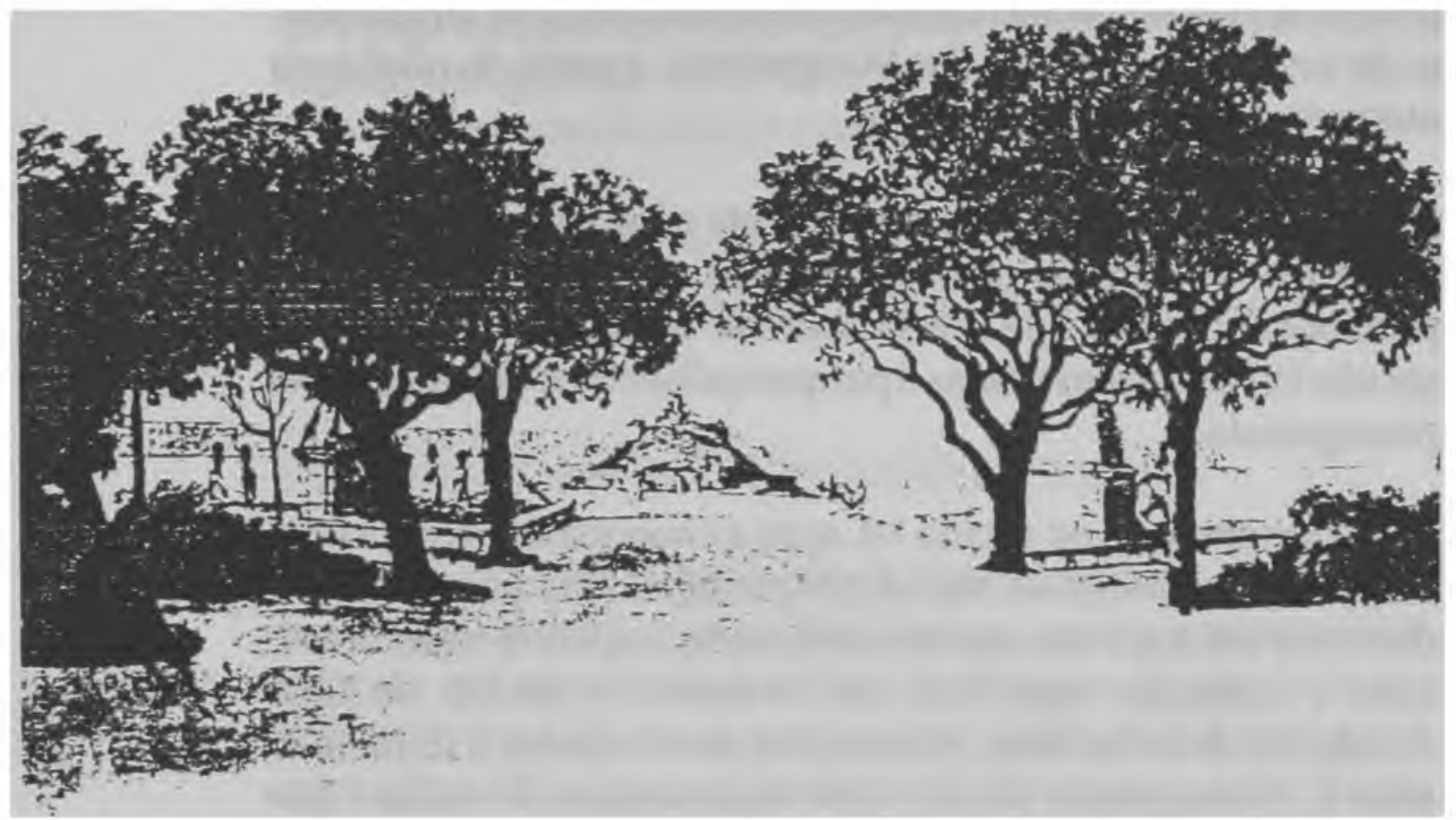

Figura 7 . O Passeio Público por volta de 1817, desenho a lápis e aquarela de Thomas Ender, visto a partir da alameda central no sentido do mar, mostrando ainda os traços originais do Mestre Valentim.

Embora com a mesma denominação do seu equivalente na Lisboa Pombalina, o passeio público do Rio de Janeiro não guarda nenhuma semelhança com seu homônimo português: Mestre Valentim irá procurar seus modelos de referência indiretamente - nos jardins da escola francesa filiada à linha de Le Nôtre (jardins de Versailles e Vaux-le-Vicomte), adaptado às condições mesológicas locais, nos exemplos encontrados até hoje nas chácaras equintais pernambucanos de Nassau. (Mariano Filho, 1943)

Assim, mestre Valentim define o que José Mariano Filho denominou como os "princípios essenciais para a composição dos jardins tropicais", definido por uma composição geométrica composta deliberadamente com ruas estreitas, visando o objetivo essencial de "sombra", efeito este obtido através de uma arborização densa de alto porte, com elementos florísticos de "sub-bosque" 
Obra de engenharia de grande vulto - até para nossos dias - a relevância do passeio público não se limita simplesmente ao projeto do jardim, como também a primeira obra de arrasamento de um morro (o morro das Mangueiras), a partir do qual seria aterrada a lagoa do Boqueirão.

Outrossim, o passeio público representa o início de um processo gradativo de substituição dos marcos religiosos por marcos profanos, processo que iria se acelerar na segunda metade do século 19, no qual as praças e parques públicos teriam um papel protagonista.

Posteriormente, já no século 19, após a chegada da Família Real em 1815, por iniciativa oficial é encarregado Joaquim Lebreton de reunir artistas franceses decididos a acompanhá-lo ao Brasil, com a intenção específica de constituir o núcleo de uma Academia de Belas Artes, na tentativa de incorporar à Corte toda uma (...)"concepção de arte e de organização do espaço que correspondia à Europa da razão burguesa, contemporânea da Revolução Industrial e do trabalho assalariado" (Abreu, 1987)

Destes artistas, um principalmente deve ser considerado o mentor das primeiras reflexões urbanísticas sobre o Rio de Janeiro, originadas a partir de sua experiência adquirida em capitais agitadas por permanentes obras de remodelação urbana: Grandjean de Montigny.

Formado na tradição neoclássica da Ècole de Beaux Arts, Grandjean interpreta a cidade na sua potencialidade cenográfica como suporte da exibição do trono europeu e, posteriormente, o poder imperial brasileiro, embora sem ter - pelo menos no início de sua estadia - uma idéia concebida da remodelação da cidade em seu conjunto. (Benchimol, 1990)

Embora as propostas urbanísticas de Grandjean, nunca tivessem saído do papel, tendo como testemunho da sua obra alguns dos poucos edifícios públicos construídos, como o prédio da praça do Comércio (atual Casa França-Brasil) ou o modesto Edifício da 
Real Academia de Belas Artes (demolido, já em nosso século, no Estado Novo), é inegável que a sua presença atribui continuidade a saga da parceria entre o Estado e o arquiteto/urbanista/paisagista, inaugurada com a obra de mestre Valentim, no que se refere a discussão do espaço e paisagem da cidade. (Santos, 1979)

\section{O RIO DE JANEIRO DO SEGUNDO REINADO E AUGUSTE MARIE FRANÇOIS GLAZIOU}

\section{O ROMANTISMO NO CONTEXTO EUROPEU}

Ao referir-nos ao Rio de Janeiro da segunda metade do século 19 e, particularmente, a obra de Glaziou, estamos concomitantemente nos remetendo à institucionalização da atividade paisagística na cidade, e sua conseqüente interface com as intervenções urbanísticas que moldaram definitivamente a sua feição.

Tal remissão adquire outros desdobramentos quando este período é visto à luz da irrupção do romantismo no Brasil, quase um século após o início de um verdadeiro surto deste movimento filosófico-artístico na Europa (século 18), a partir dos ideais libertários propalados, entre outros, por Jean-Jacques Rosseau (1712-1778).

O romantismo, herdeiro da verdadeira "revolução intelectual" que se processa nos séculos 17 e 18, contrapõe-se às outras doutrinas dos seus contemporâneos, que privilegiavam o império da razão como guia infalível da conduta e da verdade.

Contrariando, portanto, o racionalismo cartesiano (Reneè Descartes/1632-1677) e os posteriores conceitos principais da ilustração (particularmente Voltaire), o romantismo se coloca, basicamente como uma teoria anti-racionalista, ao interpretar que nos problemas essenciais da vida do homem, é muito mais seguro confiar nos sentimentos. 
Porém, ambos - romantismo e ilustração - coincidiam no que tange a melhor estrutura social, que deveria estar pautada pela simplicidade e naturalidade, em contraposição à afetação característica da aristocracia.

Embora seja o romantismo que irá encampar o mito do "nobre selvagem", cujo "modus vivendi" seria preferivel a do homem civilizado com toda sua hipocrisia e leviandade (as monarquias absolutistas somadas à sociedade industrial e suas contradições) que serviria para perpetuar a tirania de sacerdotes e governantes, o que o coloca em visceral oposição ao cartesianismo "cientificista" (Leite, 1993)

A divulgação de tais idéias chega a um ponto tal, em fins do século 18 (vésperas da Revolução Francesa), que acabaram até sendo adotadas por alguns cortesãos de Versailles: a própria rainha Maria Antonieta fez construir uma "aldeia rural" elegante num canto dos terrenos do palácio, onde se entretinha brincando de pastora e ordenhando vacas leiteras, com outros membros da corte.

A noção de "território" (associado à formação das nações) origina em boa parte a denominação "paisagem/paisagismo", cuja etimologia nos remete à palavra francesa "pays" (país). A discussão dessas idéias filosóficas, os estímulos das grandes viagens, a moda de colecionar trabalhos de pintores italianos do século 17, tudo contribuiu para o surgimento de novas idéias estéticas. (Laurie, 1976)

Será, portanto, no decorrer do século 18 que encontraremos a primeiras descrições de lugares reais, relacionando seus atributos físicos com a resposta emocional que eles despertavam. A sacralização da paisagem conduz a uma busca nas fontes pictóricas de uma metodologia de identificação de fontes de beleza na natureza, particularmente no que se refere a critérios abstratos de valorização do arranjo de árvores, gramados, pedras e água. 
O jardim como imitação da paisagem foi produto, portanto, do movimento romântico, cuja forma se baseava na observação direta da natureza e nos princípios da pintura. Porém, dita "imitação" é também, à semelhança do seu similar classicista (André Le Nôtre), um exercício de composição onde os referenciais morfológicos irão ser procurados nas visões idealizadas da natureza no seu estado bruto, e não na geometria estetizante dos tratadistas quatrocentistas.

Face a isto, as linhas de projeto e os objetivos da arte da paisagem pitoresca, assim fundamentada, passaram a ser a surpresa, a variedade, a simulação e a sequiência de idílicas perspectivas (Laurie, 1976), visando, principalmente, o efeito dramático do resultado final, no seu conjunto.

\section{LONDRES E AS PRAÇAS ARBORIZADAS DE PARIS}

Durante seu exílio em Londres, Luis Napoleão ficou visivelmente deslumbrado com as praças e parques ingleses a um ponto tal que, uma vez no poder, uma das suas primeiras idéias foi incorporar à sua cidade áreas verdes similares: imensos parques românticos e praças com arborização e arbustos, totalmente inéditos em Paris.

Porém, sob o ponto de vista urbanístico, as áreas verdes que decorreram de tal intenção, diferiam nitidamente das suas similares londrinas em vários aspectos, particularmente no que se refere à sua localização: enquanto as praças inglesas eram isoladas do tráfego de veículos, as de Paris eram conseqüência de um alargamento de ruas.

Isto originou uma clara e original tipologia de praça, que constituiu a novidade urbanística mais imitada nos anos imediatamente sucessivos à tal intervenção (Plano Haussman). A grande capacidade do engenho de Haussmann, como organizador do Plano de Reforma de Paris, se faz evidente no sistema de parques que criou em grande escala e segundo os princípios de uma grande escola. (Giedion,1978) 
Derivavam estes parques daquele tipo de jardins pitorescos "à inglesa" que imitavam a natureza, freqüentemente com tendências românticas e contendo, nos seus limites, montanhas, vales, lagos e rios em miniatura. Foram criados para serem objeto de todos os olhares, e desfrutados por suas vastas perspectivas e profusão de verde.

Porém, principalmente, foram introduzidas pelos franceses, plantas jamais vistas, até então, em jardins públicos no mundo todo. Como diz Giedion:

(...)" "Resultou que os antigos mestres da jardinagem, os ingleses, agora vinham à Paris para aprender como empregare introduzirnos jardins ingleses, um "novo aspecto em sua vegetação" (...)

As novas espécies tropicais e subtropicais empregadas eram robustas, em quase sua totalidade exótica, que Adolphe Alphand, engenheiro-paisagista a serviço de Haussmann, e seus colaboradores descobriram e trouxeram para Europa em ricas variedades. (Alphand, 1868)

Entretanto, a jardinagem exótica não é aqui inédita: ela foi um fenômeno tipicamente europeu. Itália, Espanha, Viena, França e, particulamente, Holanda (principal centro de botânica e agricultura em fins do século 17), eram os principais centros, embora Inglaterra tivesse participado sempre desde o início. (Thomas, 1989)

Isto pode ser atribuído - em boa parte - ao impressionante acervo de desenhos e herbários que alguns países europeus tinham acumulado nos séculos anteriores, produzidos e recolhidos por inúmeros pintores e cientistas viajantes das numerosas expedições científicas. 


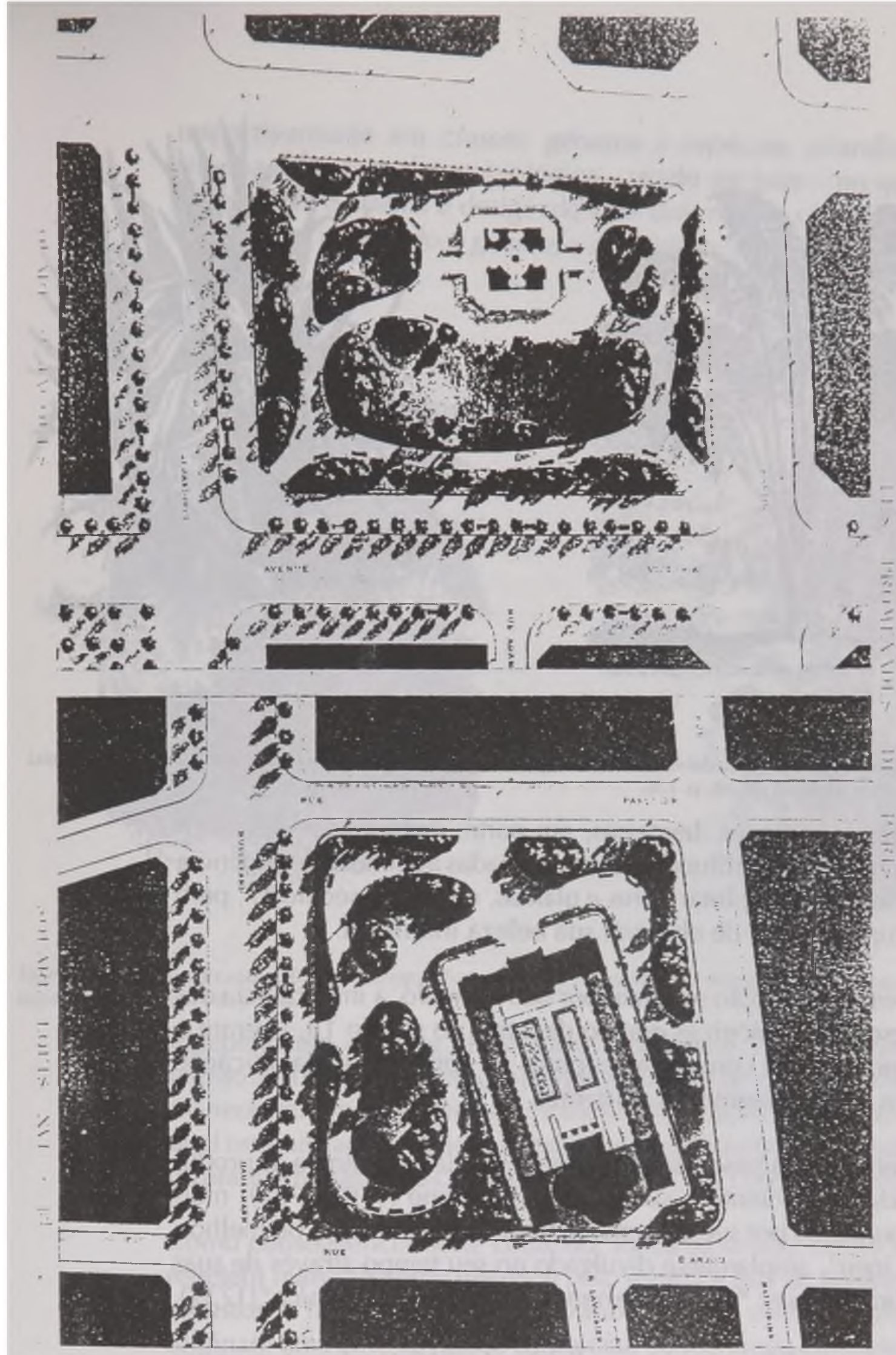

Figura 8 - Os squares St. Jacques e Louis XVI, segundo Alphand, Les promenades de Paris, J. Rothschild Editeur, 1868. 

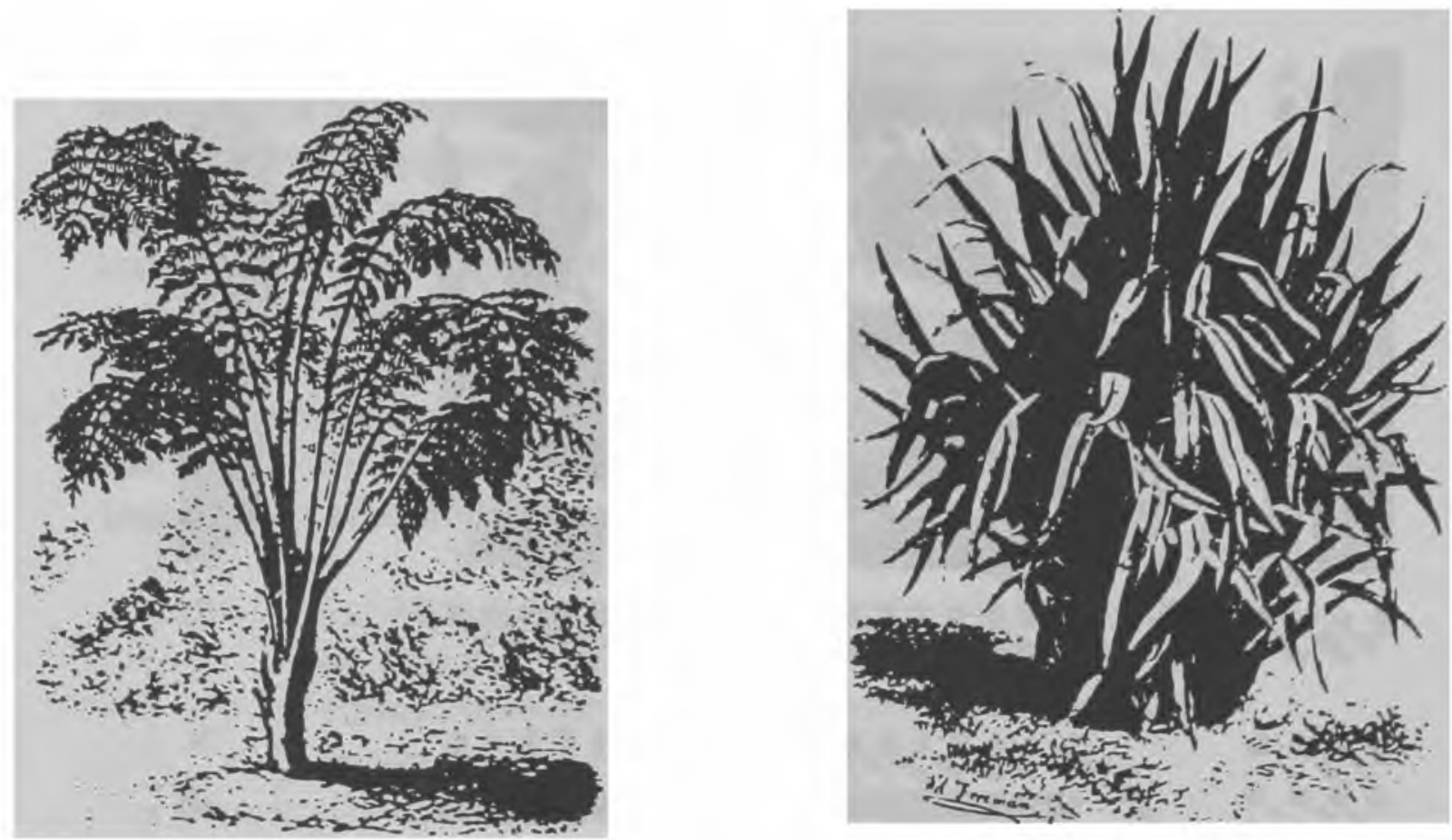

Figura 9 - Especies utilizadas no Bois de Boulogne, Fougeres (cibotium princeps) e Liliacées (phormium tenax), segundo Alphand, op. cit., p. 136.

Estas expedições, herdeiras, em parte, dos grandes descobrimentos, estão profundamente associadas à acentuada tendência a desenhar ou pintar flores e plantas, durante o século 17, pelo simples prazer de observar sua beleza intrínseca.

A esta associação se soma, por outro ângulo, a importância das pesquisas biológicas que no decorrer do século 18, tiveram a tendência de concentrar esforços na definição e classificação dos conhecimentos já existentes.

Dentre essas pesquisas adquirem especial relevância as produzidas pelo cientista sueco Carl von Linné (1707-1778), mais conhecido por seu sobrenome latinizado "Linneus" ou melhor, "Lineu", amplamente divulgado no seu tempo através de suas obras-primas: "Sistema da natureza"e "Crítica botânica"(1737).

É a partir delas que surge a divisão dos objetos da natureza em três reinos (mineral, animal e vegetal), os quais são classificados, 
respectivamente em classes, gêneros e espécies, criando o sistema de nomenclatura biológica - usado até hoje - no qual cada planta e animal é designado com dois nomes científicos: o primeiro, indicando o gênero, e o segundo, a espécie.
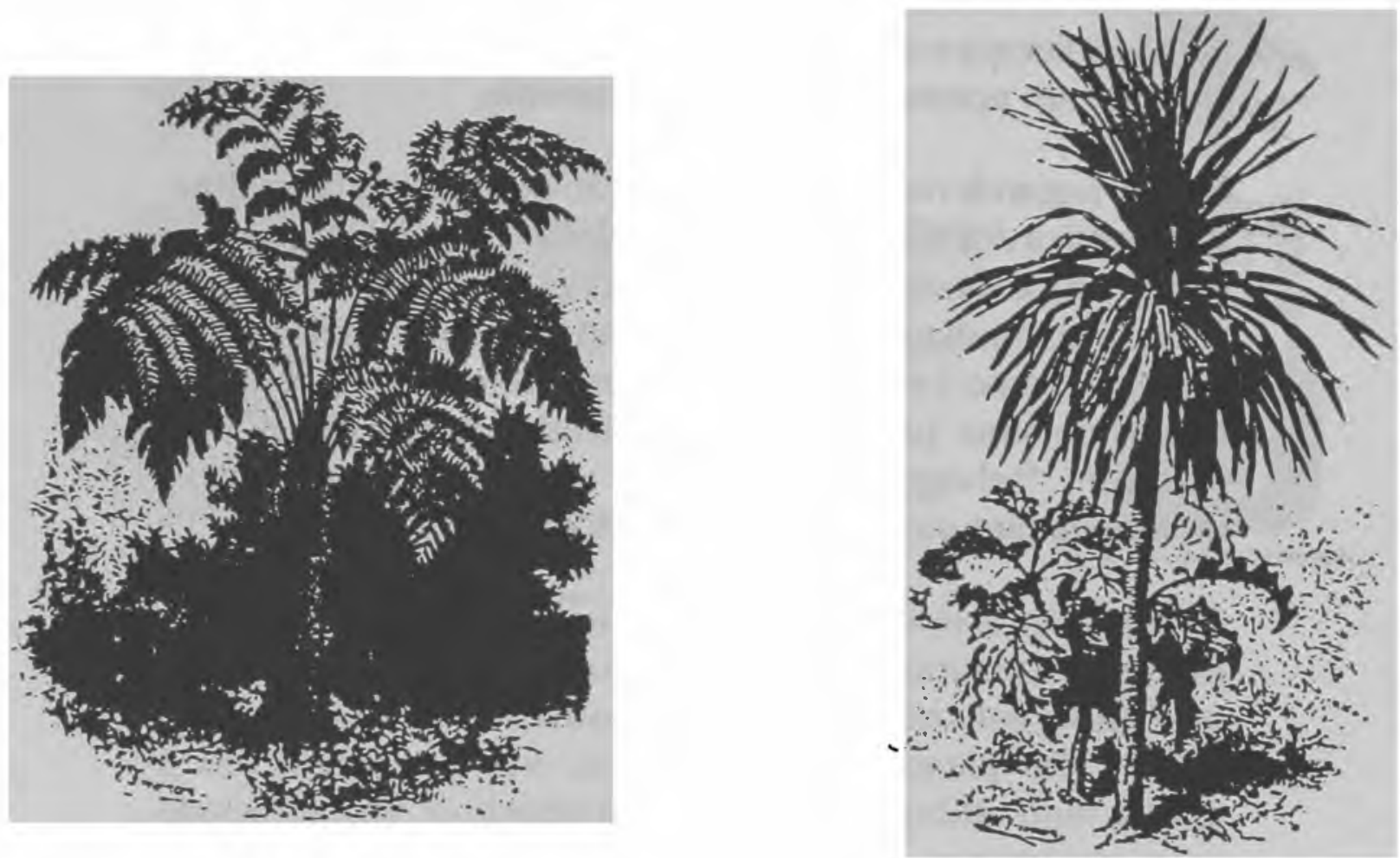

Figura 10 - Espécies utilizadas no Bois de Boulogne, Fougeres (alsophila australis) e Liliacées (dracaena draco), segundo Alphand, op. cit., p. 132.

Independente do rigor classificatório de Lineu, o seu grande mérito reside na sua aceitação de que o número de espécies "não foi necessariamente fixado no momento da criação", razão pela qual estimula aos botânicos a dedicarem seu talento à produção de plantas novas, pelo cruzamento de espécies. (Thomas, 1989)

Como conseqüência deste contexto, todos os fatores acima se refletem num crescente interesse pelo estudo e uso de árvores, arbustos e flores tanto nativas como também exóticas, que originam uma forte atividade comercial, concentrada em fontes organizadoras de suprimentos de mudas e sementes, assim 
como o invento - e produção industrial - de maquinário necessário para o plantio e conservação.

Assim mesmo, as espécies exóticas, que na forma de um volumoso fluxo de exemplares (flores, arbustos, árvores, tanto na forma de mudas como de sementes) vindas do mundo todo, invadem Europa e seus mercados horti e floricultores, geram um crescimento acentuado do seu uso corrente.

Porém, o grande mérito da contribuição do emprego da jardinagem exótica dos franceses (Alphand) sobre o modelo romântico inglês, reside na sua capacidade em criar um clima de surpresa, variedade, simulação e a conseqüente criação de idílicas perspectivas, como forma de reconhecer a beleza não apenas na ordem de uma paisagem "domesticada" como na de uma paisagem "selvagem" (construída) sacralizada nos mesmos moldes da pintura paisagística ou pitoresca.

A vegetação, assim usada, passa a ter um papel predominante na estruturação compositiva do espaço externo, a partir das suas qualidades volumétricas, que somada a uma verdadeira "modelagem" dos planos (elevação, lagos, riachos, pedras, etc.), resulta num atributo "dramático-introspectivo" tão apreciado pelo movimento romântico. Será este, portanto, o atributo diferenciador mais notável que irá estabelecer um claro limite entre o jardim classicista francês e seu similar romântico.

Como expressa um contemporâneo de Haussmann, o jardineiro paisagista William Robinson, cujos livros exerceram grande influência sobre a jardinagem britânica do século 19 (1869), ao referir-se as novas praças de Paris, o que mais impressionava os visitantes estrangeiros destes espaços, era seu frescor, o esmero no seu cuidado e o grande número de pessoas que os freqüentavam. 


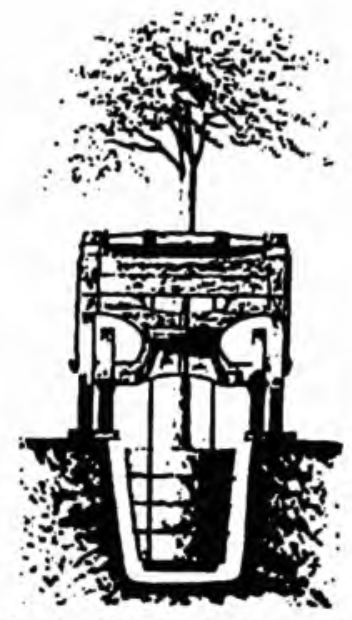

54. 16. Strotion de Terent-tria.

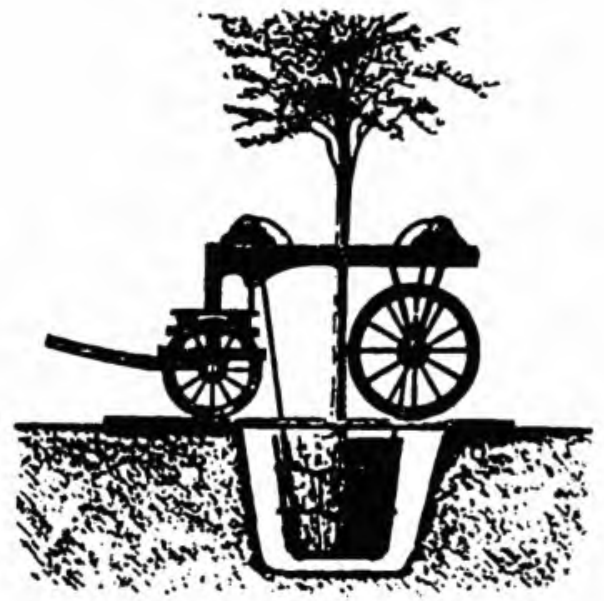

Fig. 57. Etsration toldinle.

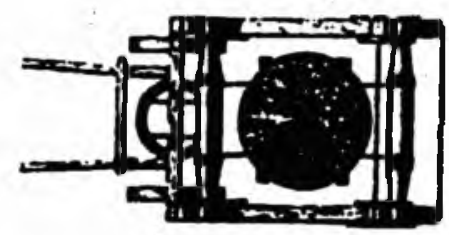

78. 10. Nen de etravion. ctant on o, an

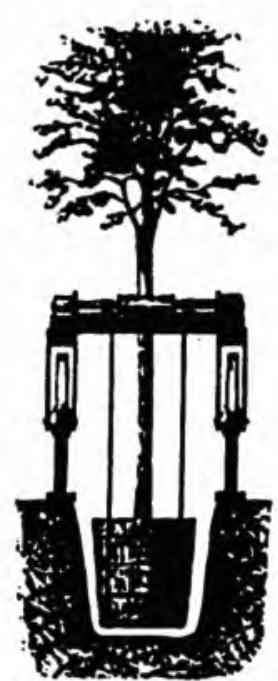

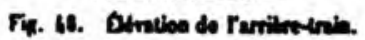

Figura 11 . O pequeno chariol (carro) empregado na execuçăo do bois de Boulogne para o transplante e Iransporte de mudas de menor porte, extraído de gravuras do livro de Alphand, op. cit. p. 47.

Da mesma forma, reconhecendo o significado social destes espaços livres públicos, Robinson estabelece uma clara distinção entre estas praças, e suas similares inglesas:

(...) "enquanto nós /os ingleses / persistimos em reservar nossas praças para que sejam desfrutadas por uns poucos privilegiados, e mantê-las, como de costume quase desprovida de qualquer planta ou arborização, eles/os franceses/as abrem para o livre uso do público, como nossos parques, e as decoram com grande variedade e riqueza de vegetação". (Robinson, 1869) 


\section{A PREPONDERÂNCIA DO PAPEL DO ENGENHEIRO NA VIABILIZAÇÃO DO PAISAGISMO PITORESCO}

Contrariamente ao que poderia fazer supor o fato de encontrarmos as origens do paisagismo romântico na escola de pintura pitoresca, ainda nos séculos 16 e 17, a materialização executiva destas obras estiveram muito mais sob a responsabilidade dos profissionais oriundos das Écoles Polytechniques do que das École de Beaux Arts (incluindo nesta última os arquitetos).
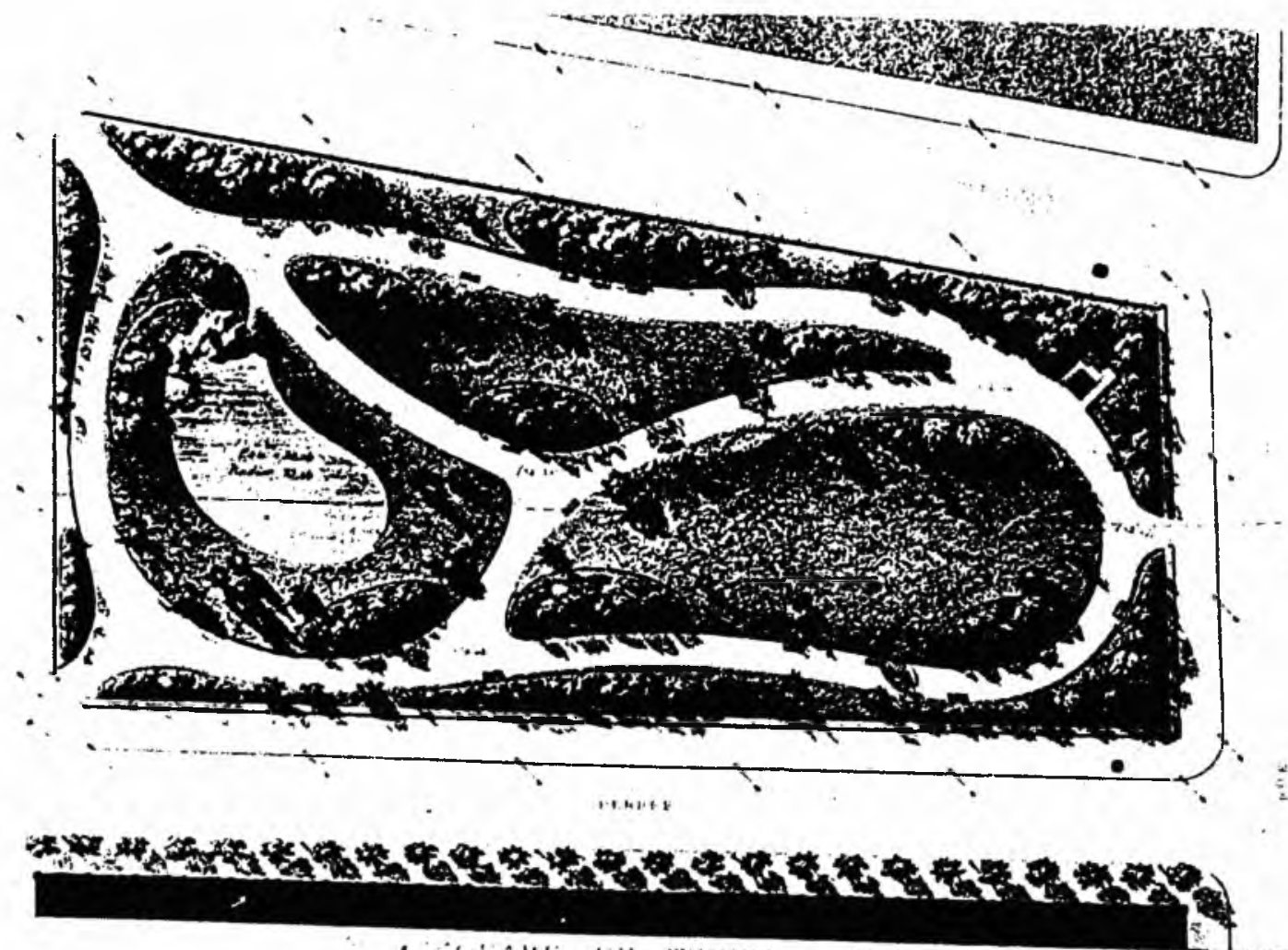

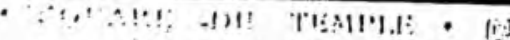

Figura 12 - O square du Temple, segundo Alphand, Les promenades de Paris, j. Rothschild Editeur, 1868.

Os problemas técnicos de execução, além das vultosas quantias de dinheiro necessárias para a verdadeira "construção da paisagem selvagem" que o parque pitoresco supunha, requer profissionais que não somente tenham uma sólida formação técnica em vários campos do conhecimento, como também uma noção 
clara dos custos envolvidos na sua viabilização, o que supõe um claro envolvimento com a praxis.

Na França esta dicotomia se acentua a partir do final do século 18, com a instituição da École Polytechnique (1795) e suas áreas de especialização, particulamente, a École des Pontse Chaussées, que englobava boa parte dos conhecimentos técnicos necessários para tal empreitada (particularmente drenagem, estudo de solos, terraplenagem, etc.).

Não é por outra razão, senão esta, que Haussmann irá reunir ao seu lado como colaboradores e assessores, para enfrentar a colossal empreitada de reforma de Paris, um conjunto de profissionais, que além de serem formados nessa escola, possuíam uma sólida experiência em administraçōes municipais.

De fato, muitos destes colaboradores, que amadureceram profissionalmente com Haussmann e sua obra, conheciam-o desde a sua gestão como administrador municipal das cidades de Yonne (como no caso de Belgrand, diretor do importante Service des Eaux et des Égouts de Paris), e, posteriormente, de Bordeaux (Bordéus), onde conhece Adolphe Alphand, na ocasião engenheiro do Service des Ponts et Chaussées, e posteriormente nomeado em Paris chefe do Service des Promenades et Plantations (1853).

Junto com M. Deschamps, recrutado do próprio quadro de especialistas da prefeitura de Paris (ao que é delegada a responsabilidade da chefia da Comissão Técnica do Plano Regulador da cidade), este grupo de engenheiros, somados a outros tantos assessores e colaboradores, constituem o verdadeiro "Estado Maior", da intervenção de Haussmann.

Outrossim, se estabelece - por muitos anos inclusive até a irrupção do Movimento Moderno e do Ciam - a tradicional ingerência do engenheiro nas questões relativas ao urbanismo em geral, que caracterizou o século 19 e primeiras três décadas do século 20. 
GLAZIOU COMO INTRODUTOR DE NOVAS IDÉIAS DE INTERVENÇÃO E GESTÃO URBANA NO RIO DE JANEIRO

A intervenção urbanística processada pelo barão Haussmann em Paris (1853-1868) teve na ocasião uma repercussão internacional notável, e em boa parte estabelece - por muito tempo um modelo naturalmente aceito de gestão pública, tanto em termos de resultados como de estrutura administrativa, gestada e ensaiada e, previamente, na sua passagem por municípios menores. (Yonne e Bordeaux)

Entretanto, reflete um processo bem francês - a disputa entre os conhecimentos da emergente École Polytechnique e a École de Beaux Arts, característica do século 19 - no qual a figura do engenheiro assume destaque evidente pelo seu rigoroso compromisso com a praxis e o pensamento positivista.

Neste contexto cultural é formado Auguste Marie François Glaziou, que nascido na Bretanha (França), em 30 de agosto de 1833, cursa a École Polytechnique D`Angers, da qual passou para a Escola Central de Paris, onde seguiu as preleções de Adolphe Brogniard (1801-1876) e Decaisue. (Garcia, 1927)

Com apenas 22 anos (1855), Glaziou foi convidado pelo prefeito de Bordeaux, Durieu de Maissoneuve, sucessor do barão Haussmann (já nomeado prefeito de Paris por Napoleão III) para dirigir os trabalhos do Horto Municipal da cidade.

Esta seqüência de fatos nos permite formular a hipótese plausível que o tipo de vinculação que Glaziou teve com Haussmann e A. Alphand, foi muito além do que uma simples filiação a uma escola paisagística, dada a importância que o quadro de funcionários da prefeitura de Bordeaux teve no recrutamento de colaboradores para a equipe de Paris.

Independente do notado valor de sua obra, um aspecto curioso que logo surge, assim que começamos a tentar aprofundar os conhecimentos sobre ela, éo grau de dificuldade para recompor 
as circunstâncias em que Auguste François Marie Glaziou aparece em nosso meio, sua formação profissional ou, ainda, o tipo de militância profissional e/ou experiência adquirida na época.

As diversas fontes em que existem referências biográficas - em sua maior parte jornalísticas - muitas vezes apresentam dados contraditórios que chegam a confundir o seu próprio nome, agravado pelo fato de o próprio assinar seus desenhos como "A. Glaziou" ou simplesmente "Glaziou"

É muito impreciso o motivo ou fato que conduziu Glaziou para o Brasil.

Por exemplo, em ocasião da vinda, na primeira metade do século, da missão francesa chefiada por Lebreton, sempre foi de notório conhecimento, as circunstâncias em que seus membros foram recrutados, quais os ideários embutidos, tanto neles como nos seus promotores (a coroa) e, inclusive, qual o retorno que alguns deles deram à Europa (por exemplo Debret).

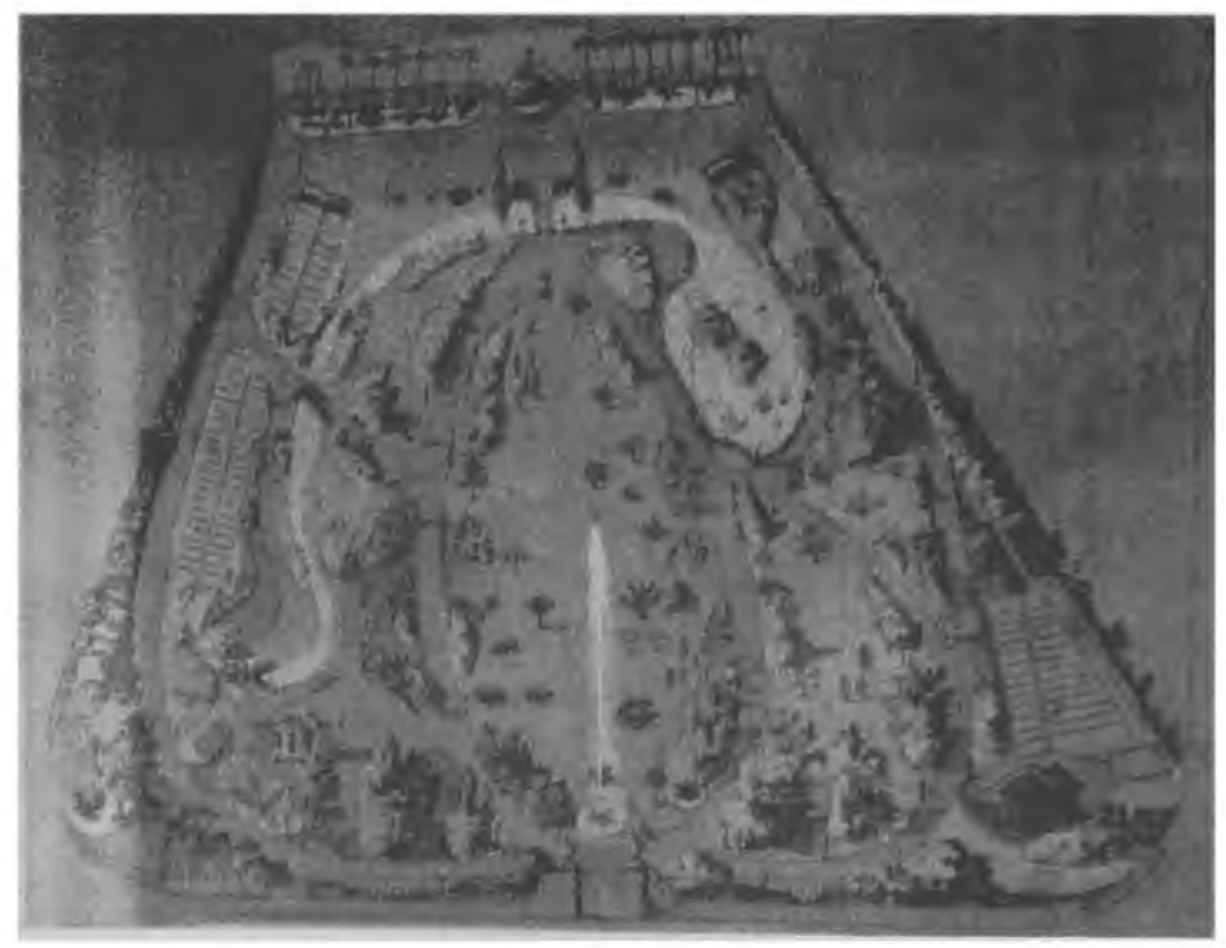

Figura 13 - O Passeio Público segundo a reforma de Glaziou, em desenho original deste, constando do acervo da Biblioteca Nacional / Rio de Janeiro. 
No caso de Glaziou, verdadeiro introdutor no Rio de Janeiro do que muitos autores costumam rotular como a expressão mais notável do romantismo (o jardim pitoresco), seu nome irrompe sem muito preâmbulo no Brasil associado à reforma do deteriorado projeto do mestre Valentim por indicação (ou contratação) de um homem de negócios muito ligado a D. Pedro II o Sr. Francisco José Fialho, em 1860.

A propósito, Paulo Santos nos fornece outras pistas, embora sem citar fontes, ao se referir ao fato de Francisco Fialho em uma estadia, mais prolongada na França, ter contratado Glaziou para executar um jardim ou parque à rua Monte Alegre, no bairro de Santa Tereza, no Rio de Janeiro em mansão de propriedade da família Fialho.

O projeto e obra do passeio público foram executados em prazo relativamente curto, se levarmos em conta a considerável alteração que Glaziou introduziu no projeto original do mestre Valentim (1861-1862).

Reforma que, diga-se de passagem, até hoje suscita não poucas polêmicas, e até ressalva de alguns estudiosos que, endossando as clássicas críticas de José Mariano Filho censuram Glaziou, neste caso, pelo:

(...) "profundo desprezo pela tradição/ luso-brasileira / da cidade, que levou o paisagista francês a devastar completamente o jardim/ de mestre Valentim / para sobre os destroços da área devastada delinear um novo traçado ondulante, com pelouses, lagos e penedos/rochas / no genêro do parque "Des Buttes-Chaumont" de Paris" ... (Mariano Filho, 1943) 


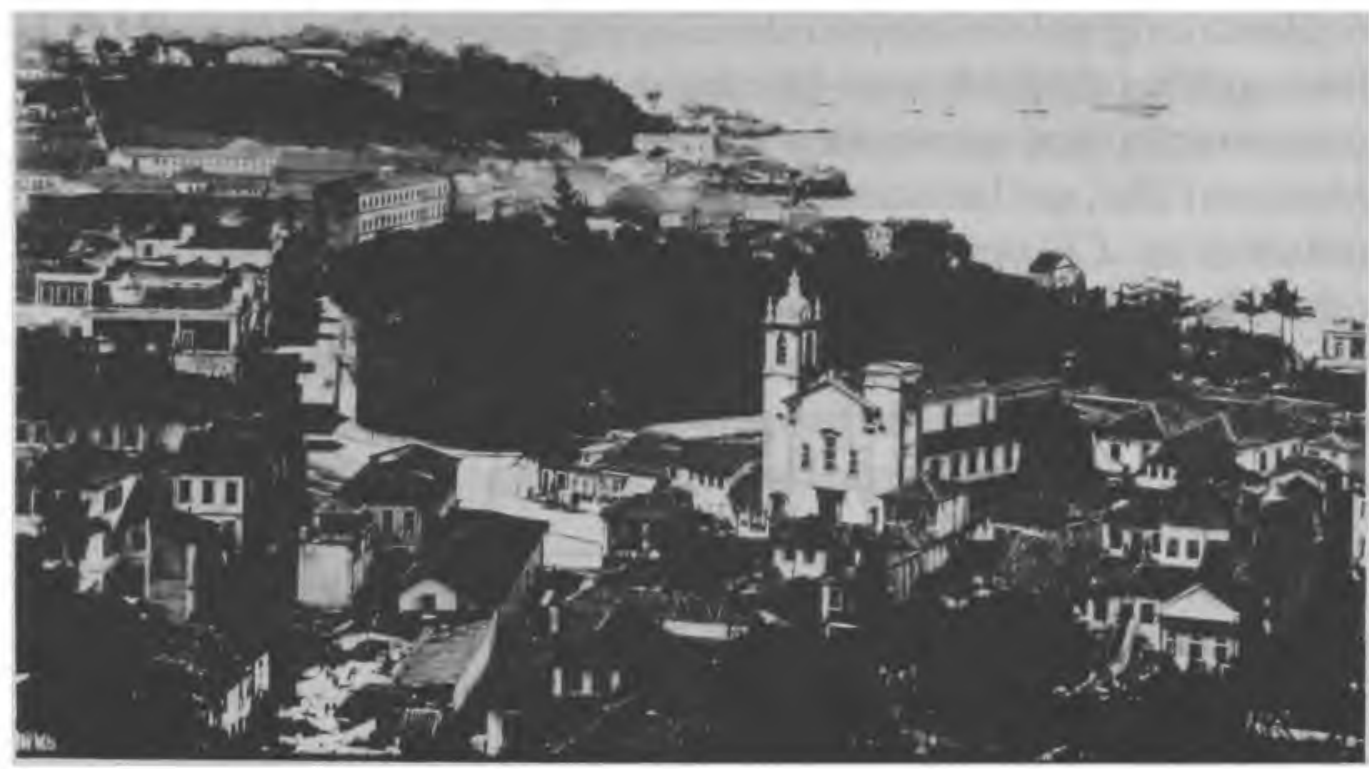

Figura 14 - Vista aérea do Passeio Público, desde a ladeira de Santa Tereza, monstrando os jardins $e$ adjacéncias com as árvores constituindo um maciço verde de porte. Na cobertura destacada na esquina da rua do Passeio com o largo da Lapa, vemos o lugar onde residiu Glaziou, como consta na planta original mostrada anteriormente. Foto de Marc Ferrez, c. 1875/Arquivo Geral da Cidade do Rio de Janeiro.

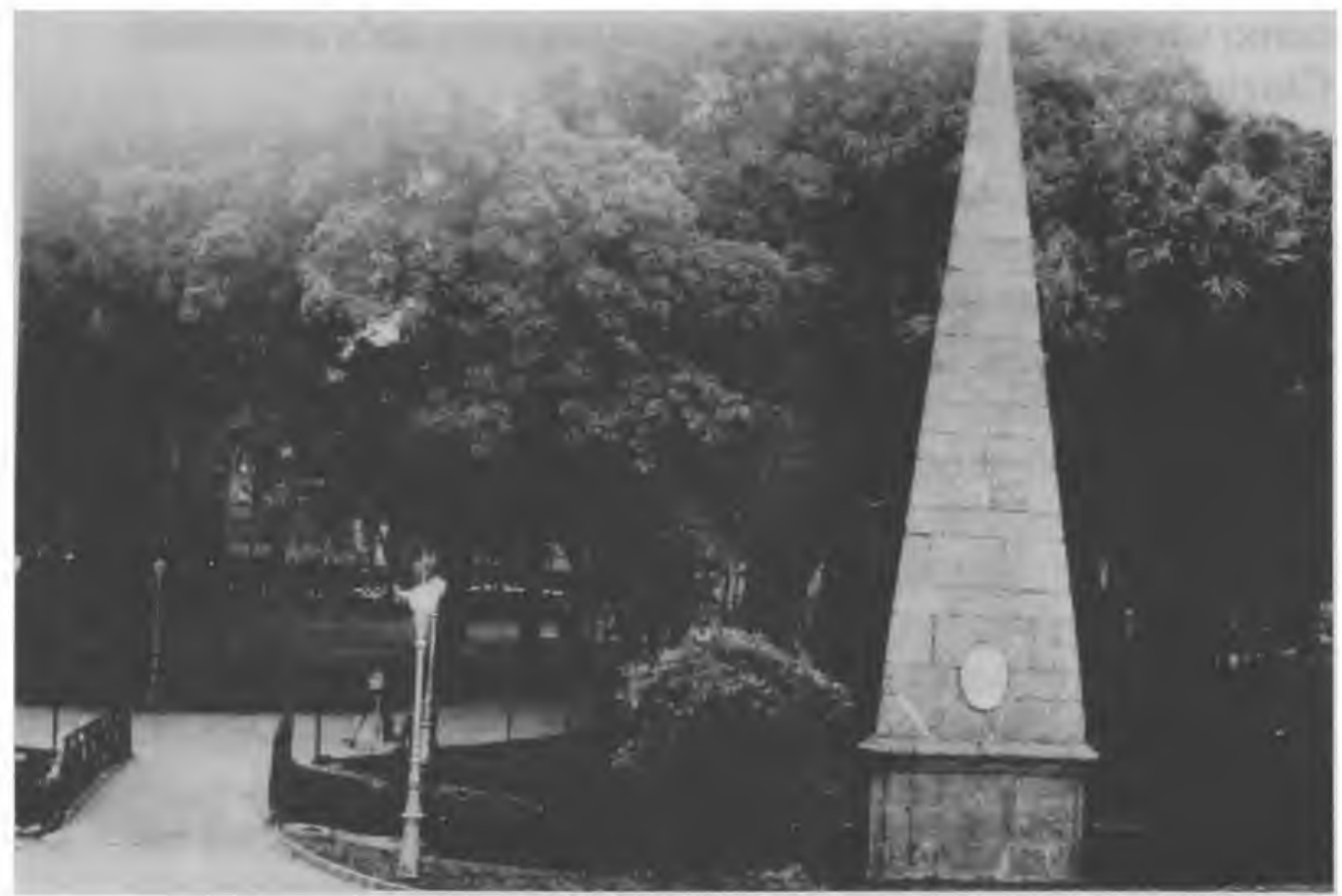

Figura 15 - Concomitante com o espirito romântico, uma série de elementos construtivos produzidos industrialmente - em sua maioria produzidos e comprados na Europa - se aliavam na ambientação rústica pretendida tais como, pedras, lagos e cascatas artificiais, ou ainda, pontes de ferro imitando galhos cortados de árvores. Foram mantidas as agulhas em forma de pirâmides do Meste Valentim. Foto de Marc Ferrez c. 1880/Arquivo Geral da Cldade do Rio de Janeiro. 
A planta original do projeto de Glaziou, integrando o acervo iconográfico da Biblioteca Nacional e em péssimo estado de conservação, nos apresenta a partir da fotografia do livro de J. Mariano Filho, um belíssimo desenho que era traço marcante no trabalho de Glaziou, e que se caracterizava por apresentar rebatidos todos aqueles elementos que significassem uma dimensão vertical dominante, com árvores, monumentos, repuxos ou construçōes, sugerindo uma vista cavalheira ou axonométrica, e a projeção de suas sombras.

Dita forma de representação aliada ao detalhado uso da cor, chegando aos requintes de retratar os claro-escuros das folhagens (que chegam a evidenciar até textura), transformava o "plano geral" num instrumento operacionalmente apto tanto para apresentação da idéia como para sua própria execução.

Embora não com esse refinamento da representação, dita modalidade será incorporada naturalmente, até começo do século 20 , como vários projetos de alguns discípulos seus, após a morte de Glaziou, apresentavam.

Junto com a estrutura macrocompositiva básica, composta por desenhos sinuosos de caminhos, maciços de vegetação, tabuleiros de relva entre-semeados de árvores de grande porte, em grupo ou isoladas, lagos, ilhas e rochas artificiais, aparecem naturalmente-todo um conjunto de equipamentos eedificações em grande parte trazidos da Europa.

Assim, pontes (em ferro fundido) rústicas e renascentistas, pavilhão imperial, bancos, estátuas de ferro representando as estações, guaritas de madeira (até pouco tempo existentes), a insubstituível edificação neogrega, tendo à frente um peristilo ladrilhado de mármore, formado por quatro colunas de ferro da ordem corintia, e até um pavilhão rústico tendo no centro um vaso Luis XV, com flores e frutos em ferro fundido, completavam o cenário do imaginário romântico. 
Sem dúvida a relação entre tais elementos é a melhor exemplificação daquele estado de espírito ligado à figura da evasão para o sonho e da fantasia que caracteriza o romantismo.

Independente da terminologia "passeio" adotada em fins do século 18 já no projeto de mestre Valentim, a partir de denominação do seu similar na Lisboa pombalina (embora sem ter nenhuma semelhança com este), o Passeio Público de Glaziou esteve muito mais para a tipologia do "square" do que "passeio"

Com Glaziou isto fica claramente assumido, como provam alguns manuscritos dirigidos à Câmara Municipal na época como consta em carta dirigida ao presidente da Câmara Municipal, Dr. Antônio Ferreira Vianna, em 13 de novembro de 1871/ Arquivo Geral da Cidade do Rio de Janeiro:

\section{(...) "estando eu encarregado dos "squares" do Rio de Janeiro, procuro ser de maior utilidade, apesar dos sarcasmos dos maitacas" (...)}

Porém, seria quase 15 anos após, no jardim da praça da Aclamação(atual Campo de Santana), que Glaziou conseguiu fechar melhor as suas idéias compositivas, que no caso do passeio público, encontraram-se excessivamente delimitadas, até pela necessidade de conservação dos monumentos do mestre Valentim.

Assim, a cascata ornamental adquire uma escala maior, quase monumental, dando espaço à criação de grutas internas iluminadas por lâmpadas de gás dispostas estrategicamente. Um grupo escultórico de proporções também monumentais apresenta o combate de um tigre com o homem, onde, abertamente, o sentimento romântico do heróico aparece mais claramente.

Os jardins de Glaziou eram de um romantismo procurado, disciplinado, resultado de profundo conhecimento de causa, daí a classificação de "erudito" que lhe é com freqüência atribuído. (Santos, 1960) 


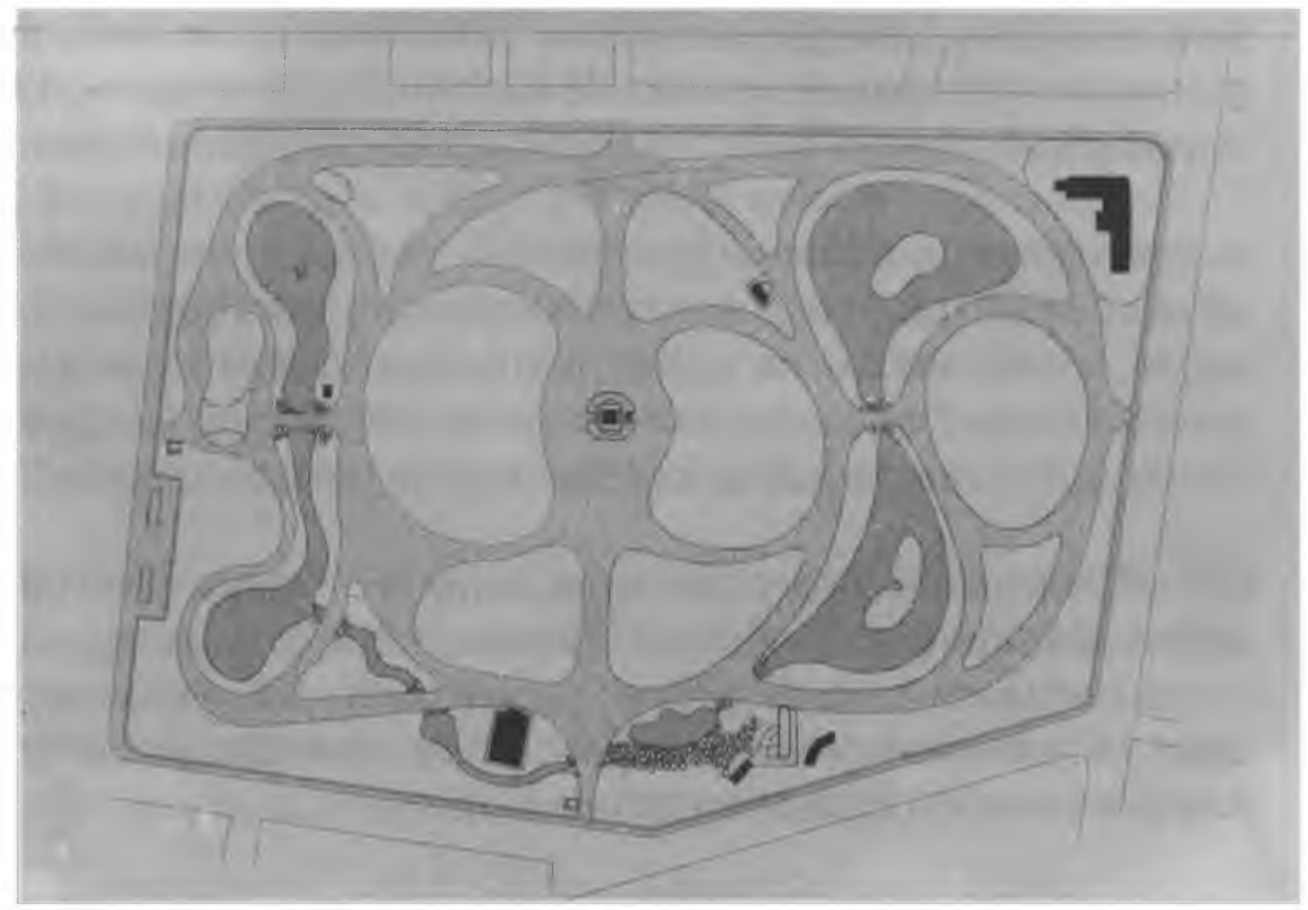

Figura 16 - Planta do Campo da Aclimaçăo (atual Campo de Santana), após a reforma decorrente da abertura da avenida Presidente Vargas (1945). Desenho: Alessandra Viude e Luiz Maurício.

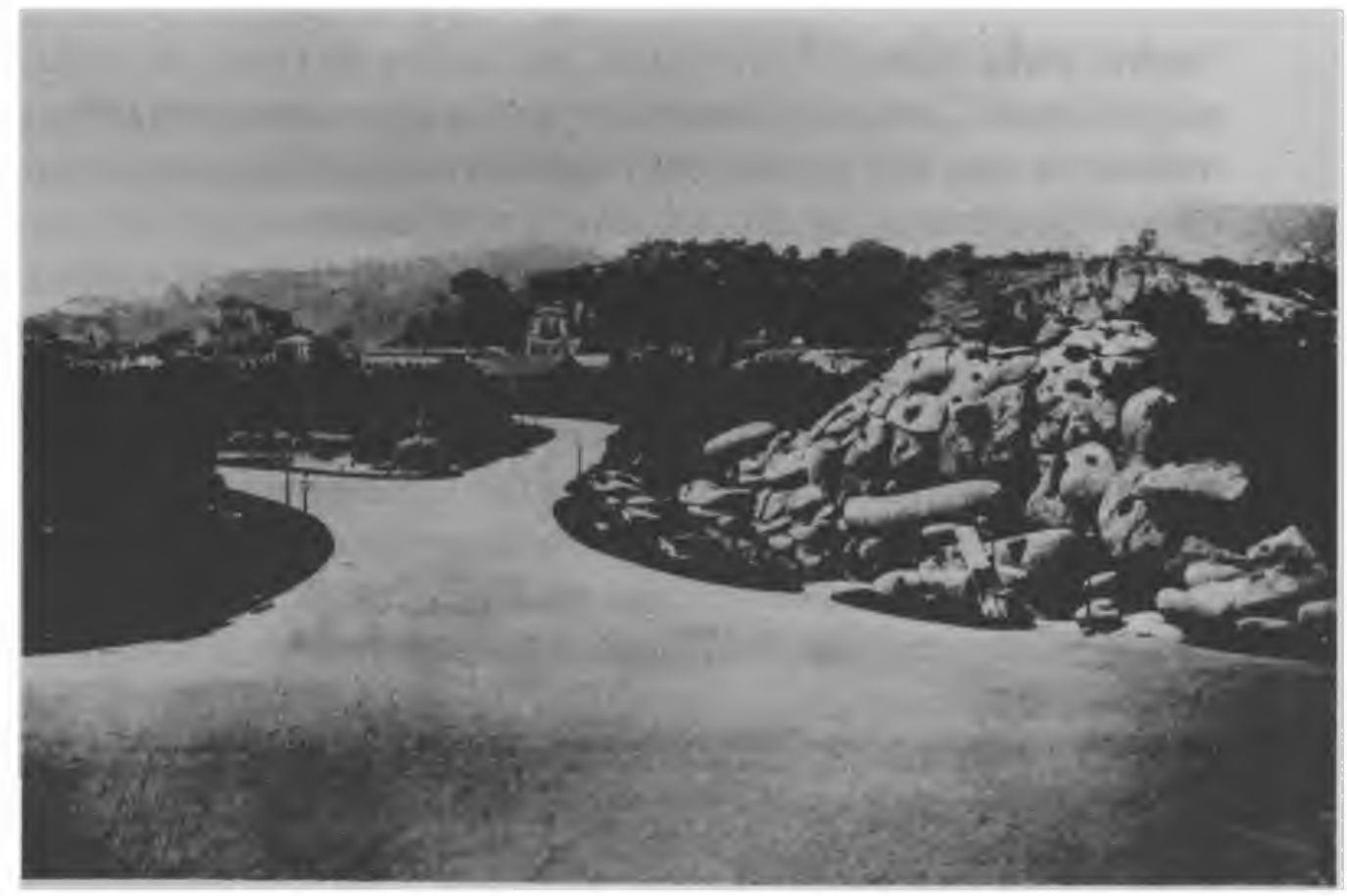

Figura 17 - Vista externa dasgrutas artificiais, em direção ao Quartel de Bombeiros e morrodo Senado (antigo morro de Pedro Dias). Ao fundo o morro de Santa Tereza. Foto de Marc Ferrez, c. 1885/ Arquivo Geral da Cidade do Rio de Janeiro. 


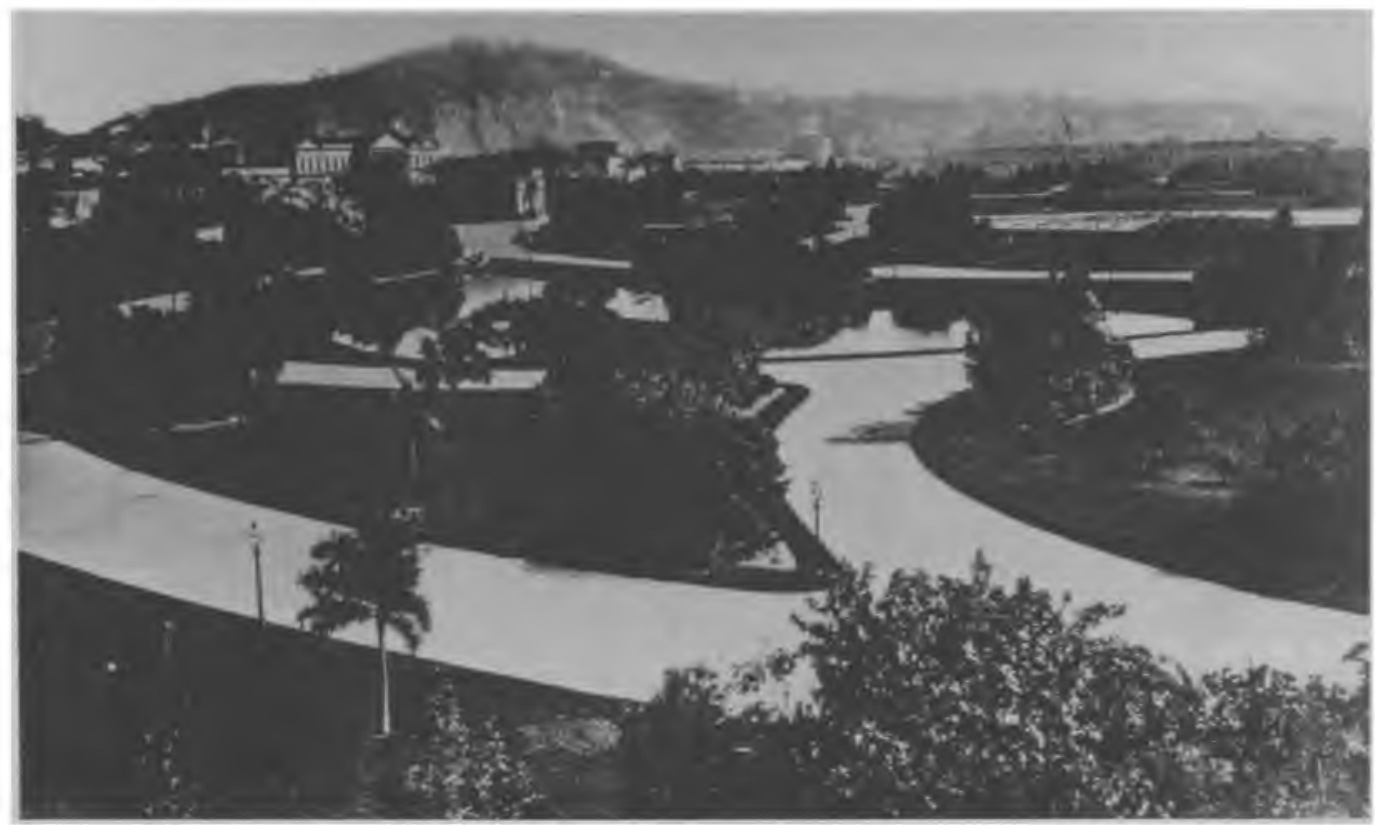

Figura 18 - O Campo de Santana (antigo Campo da Aclimação) em fotografiia em torno do ano 1885. Asárvores ainda nāo tinham adquirido o porte de lhe atribuem, hoje em dia, seu arde semi-penumbra e conseqüente, dramaticidade. Ao longe, da esquerda para a direita, o Paço do Senado, a Casa da Moeda, o Morro da Providência, a Estação de Ferro da Central do Brasil e o Quartel General. Foto de Marc Ferrez, c. 1885 / Arquivo Geral da Cidade do Rio de Janeiro.

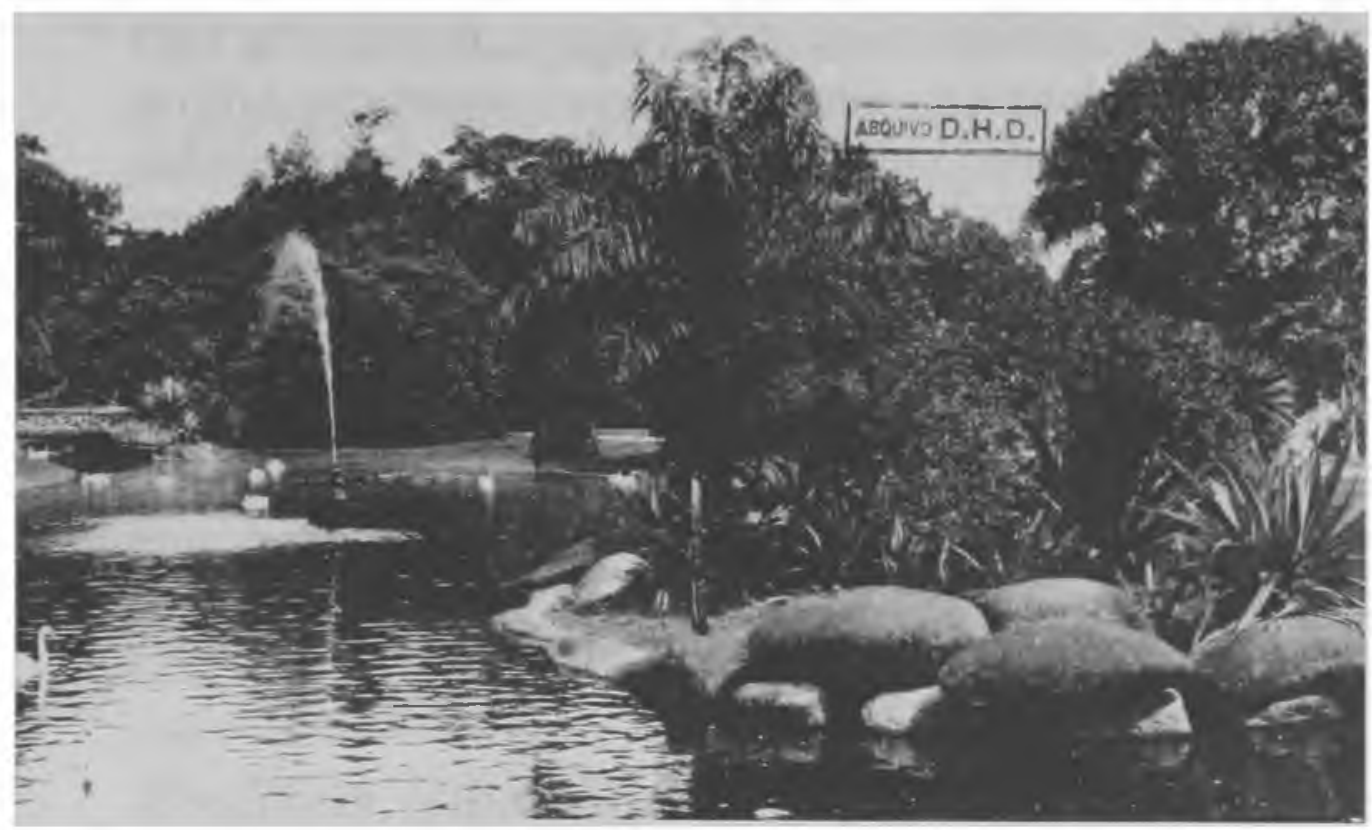

Figura 19 - Vista do largo com repuxo d’água e ilha. A imagem da ilha tem um significado muito importante no ideário romântico, inspirado na imagem da ilha de Rosseau, imagem de retórica utilizada para expressar as condições ideais de contato do homem com a natureza numa atitude de isolamento introspectivo e uma volta a suas rałzes primitivas (Mito do Eden e do Nobre Selvagem). Foto de A. Malta, c. 1910/Arquivo Geral da Cidade do Rio de Janeiro. 
O passeio público e o Campo de Santana são, para Glaziou "squares", porém a tipologia está mais próxima da reformulação de A. Alphand do que dos "squares" ingleses do século 17

Não é casual que anos depois seja Glaziou que recomende ao imperador D. Pedro II a compra do tratado de Alphand, Les Promenades de Paris, que representa, nem mais nem menos, boa parte das obras que marcaram a intervenção do barão Haussmann em Paris e, segundo Giedion, a parcela mais notável de dita obra.

Tudo indica que o então jovem engenheiro Francisco Pereira Passos, com quem Glaziou travou conhecimento através da Comissão de Obras de Embelezamento da Cidade (criada em 1874 pelo então Ministro do Império, João Alfredo Correia de Oliveira), iria consultar o tratado de Alphand com bastante freqüência na sua famosa gestão na prefeitura do Distrito Federal (1902-1906).

Embora tendo seguido a carreira diplomática, Pereira Passos permaneceu em Paris como adido à legação brasileira de 1857 a 1860, quando travou conhecimento com engenheiros da École de Ponts e Chaussées, cujos cursos freqüentou em forma assídua, assim como presenciou de forma bem próxima as obras empreendidas na época pelo Barão Haussmann. (Benchimol, 1990)

Anos depois, já em nosso século, Pereira Passos viria inaugurar como prefeito a primeira gestão municipal no Distrito Federal da 2ª fase da República (1903-1930) e, junto com ela uma seqüência de obras e intervenções, com o aval do governo Rodrigues Alves, que iria produzir a transformação do Rio de Janeiro de cidade colonial em "modema", nos termos "haussmanianos", numa escala até então nunca vista. (Oliveira Reis, 1977)

A proposta de traçado da avenida Central (atual av. Rio Branco), assim como o concurso de fachadas dos edifícios adjacentes à avenida, em boa parte foram moldados a partir das idéias contidas em tal manual, assim como o seu plano global de obras, desenvolvido no prazo recorde de apenas 4 anos. 


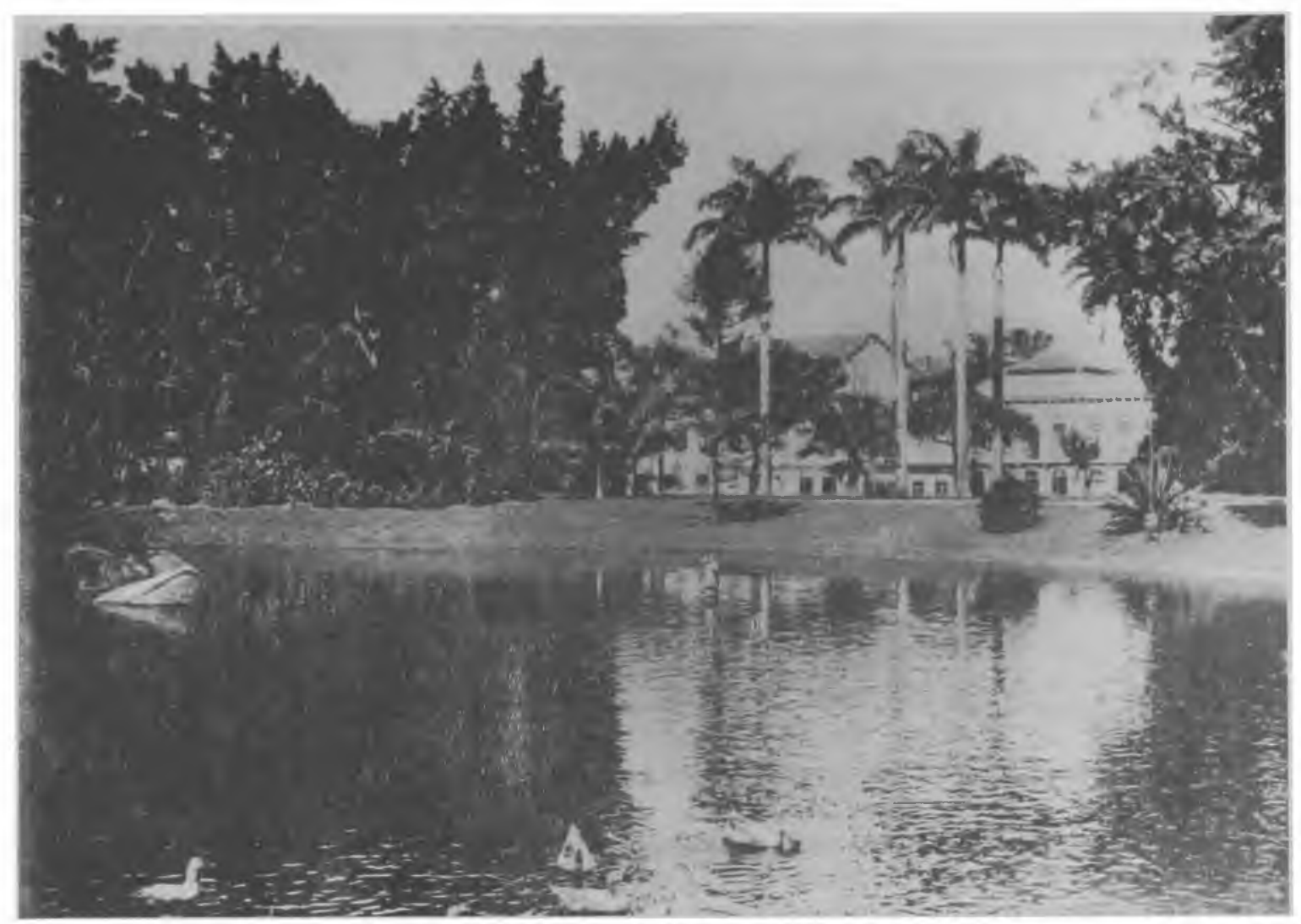

Figura 19 A - Vista do largo central do campo de Santana, 1895. Arquivo Geral da Cidade do Rio de Janeiro.

Ficaria, assim, caracterizada uma filiação direta entre Haussmann e Pereira Passos, através de Glaziou, hipótese até hoje não estudada em profundidade.

À semelhança do seu mestre Alphand, Glaziou também é nomeado, pelo Imperador D. Pedro II, diretor privativo dos jardins imperiais da Quinta da Boa Vista e Petrópolis (1868), e em 1872 Inspetor Geral dos Jardins e Parques Municipais.

Paralelamente à sua vasta atividade como paisagista, Glaziou nunca abandonou o seu prazer pela pesquisa, desenvolvida em viagens curtas no interior do Rio de Janeiro e Minas Gerais. Em 1895 integra, como botânico, a Comissão de Estudos do Plantalto Central do Brasil (Comissão de Estudos para a Nova Capital da União, conhecida por "Comissão Cruls"), levantando e catalogando toda a flora do Planalto Central, que conclui na Europa. 


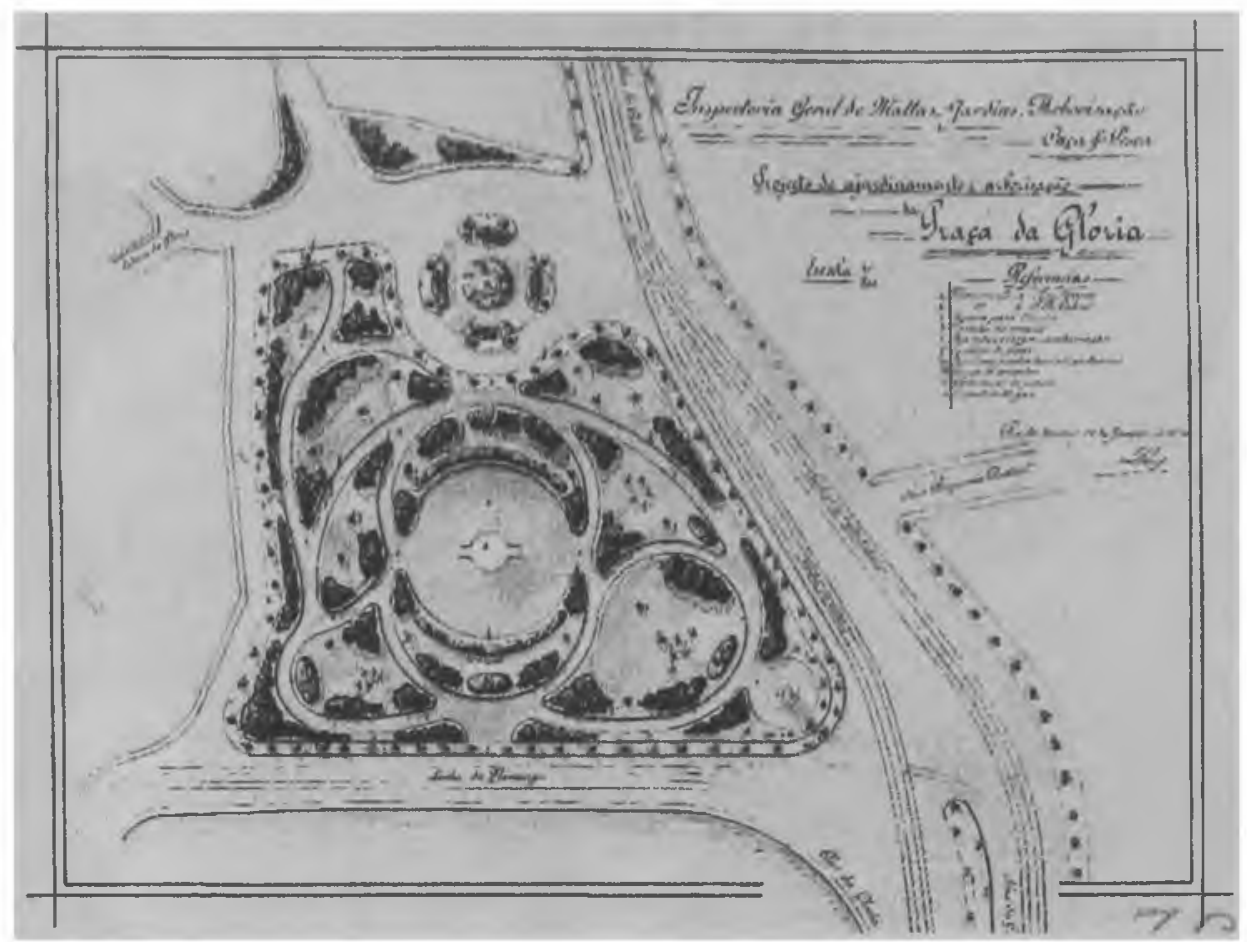

Figura 20 - Projeto de ajardinamento e arborização da praça da Gloria, 1904 / Desenho aquarelado 46,5 ×61 $\mathrm{cm}$, Coleção Museu Histórico da Cidade do Rio de Janeiro/Catalogo da Exposição: A paisagem desenhada: 0 Rio de Pereira Passos - p. 46 / outubro/1994 / Centro Cultural Banco do Brasil / Rio de Janeiro - 1994.

Em 1897 Glaziou aposenta-se do cargo de Diretor dos Jardins Públicos, Arborização e Florestas da Cidade do Rio de Janeiro (cargo para o qual foi nomeado em 01 de dezembro de 1893), e retira-se à França, na cidade de Bordeaux (coincidentemente ou não, cidade de Alphand e onde iniciou sua trajetória profissional), onde morre em 1906.

Na sua obra no Brasil, além do passeio público e atual Campo de Santana, devem ser atribuídas várias outras, das quais poucas mantêm sua feição original até os dias de hoje:

1. Largo de São Francisco de Paula (1875) (radicalmente modificado dois anos após sua execução);

2. Jardins do cais da Glória (1857);

3. Antiga praça General Osório (desapareceu completamente com a abertura da av. Presidente Vargas) (1875); 
4. Praça XV de novembro (1877) (modificada radicalmente em 1893 para se erguer a estátua do General Osório);

5. Jardins da Quinta da Boa Vista (1860-1865);

6. Jardins da residência do barão de Nova Friburgo no Rio de Janeiro (remodelado posteriormente por um discípulo seu/atual palácio do Catete)/1868;

7. Jardins da residência de campo do barão de Nova Friburgo, em Nova Friburgo (atual parque São Clemente (1868). O mais bem conservado de todos os seus trabalhos ainda existentes;

8. Largo do Machado (1873)/substituído em nosso século por projeto de Roberto Burle Marx.

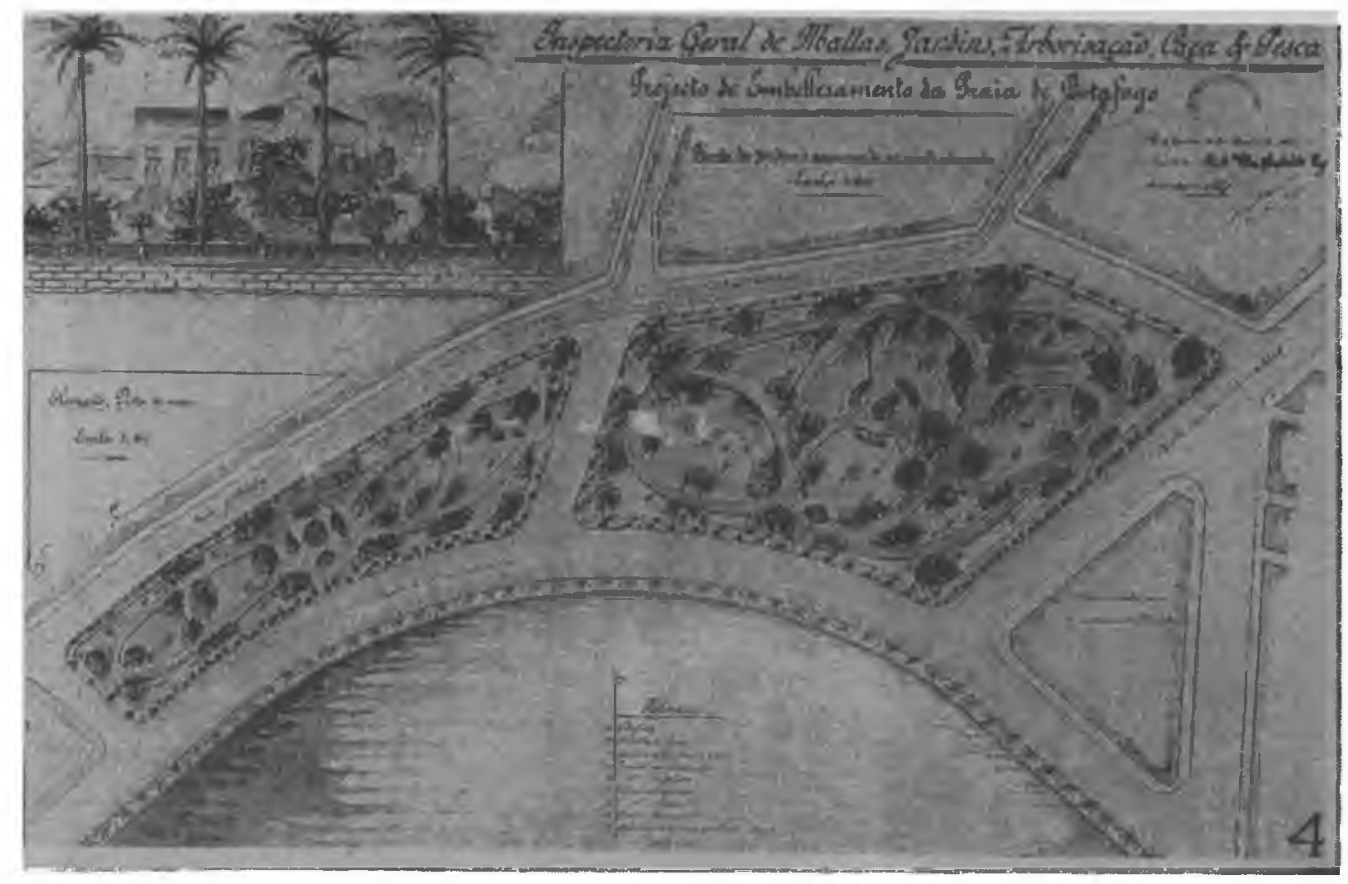

Figura 21 - Projeto de embelezamento da praia do Botafogo, 1903 / Desenho aquarelado $62,5 \times 96,5 \mathrm{~cm}$, Coleção Museu Historico da Cidade do Rio de Janeiro/Catálogo da Exportação: A paisagem desenhada: O Rio de Pereira Passos - p. 54 / outubro/1994 / Centro Cultural Banco do Brasil / Rio de Janeiro - 1994. 


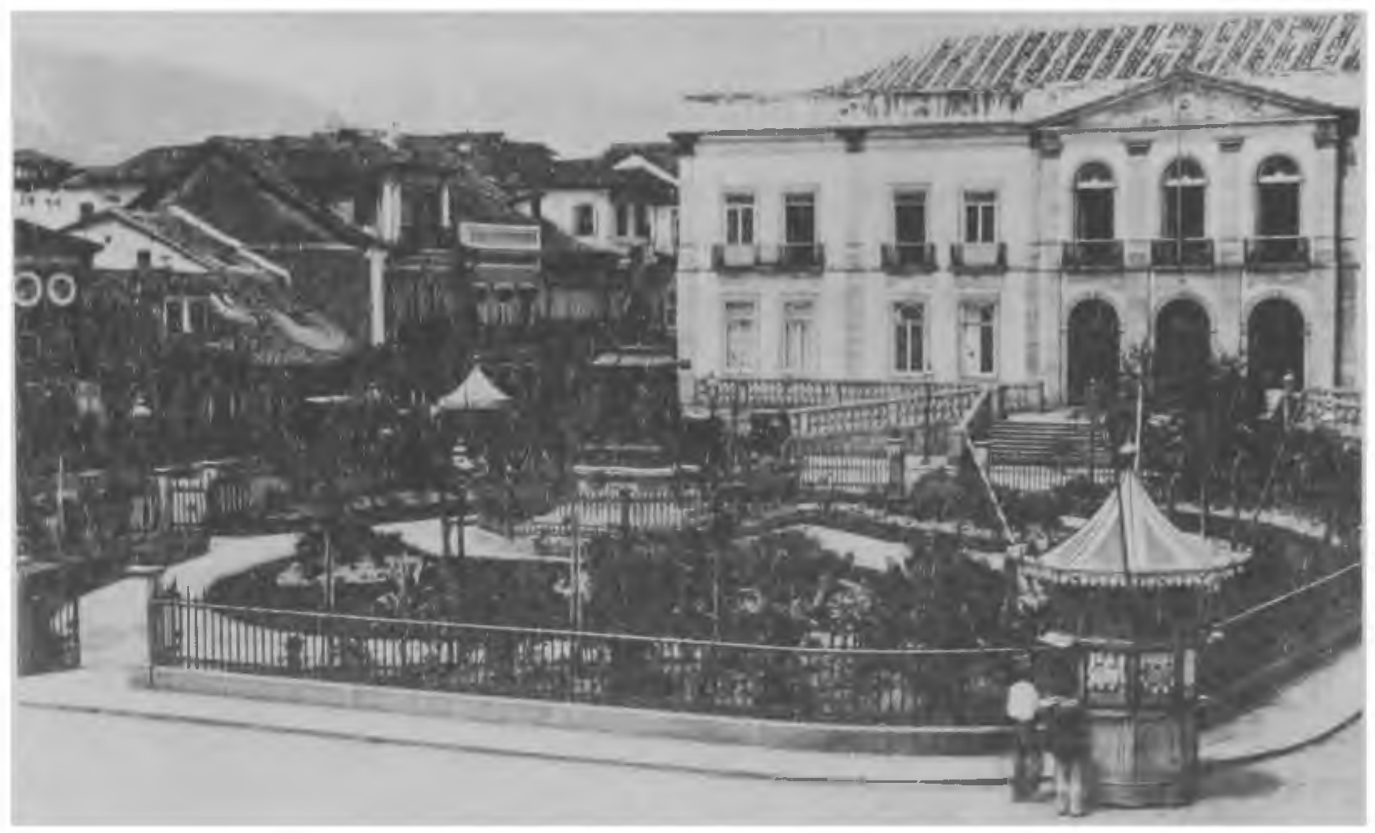

Figura 22 - Vista do jardim do largo de São Francisco de Paula, projetado por Glaziou com a estálua de losé Bonifacio de Andrada e Silva, obra do escultor francès Luis Rochet, inaugurada em 1873. Ao fundo o edificio da Escola Politécnica e a esquerda as fachadas do casário sobre a rua do Teatro. Foto de Marc Ferrez, c. 1875 / Arquivo Geral da Cldade do Rio de Janeiro.

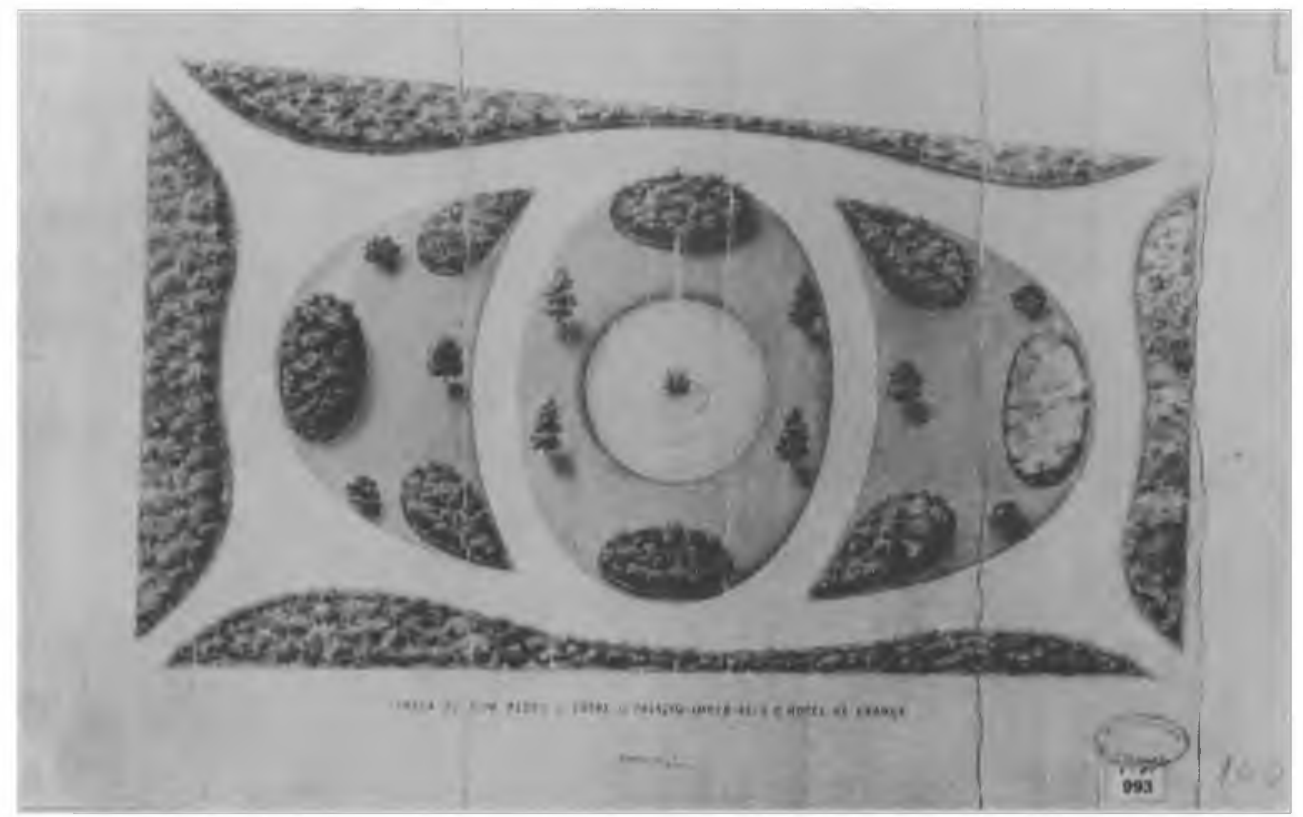

Figura 23 - Planta original do projeto de Glaziou para a praça XV de Novembro (na ocasião chamada praça $D$. Pedro III no quadrilátero situado enfrente as igrejas, parte do Paço e do Hotel de França. O jardim propriamente dito foi dividido em duas partes e no centro foi colocado um lago com repuxo / Acervo do Arquivo Geral da Cidade do Rio de Janeiro. 


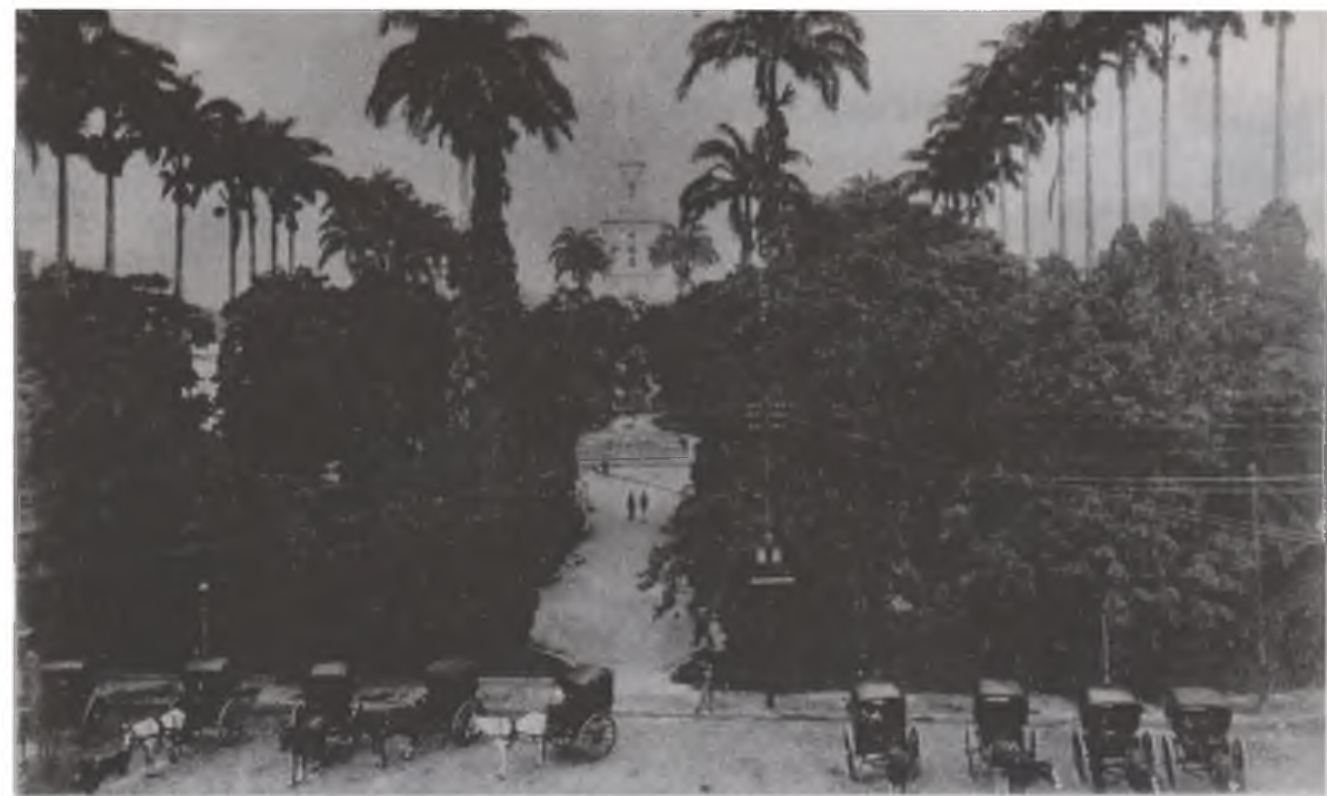

Figura 24 - Vista do largo do Machado (antiga praça Duque de Caxias) vista descle a atual rua do Cacete, que ainda mantinha as características do projeto inicial de Glaziou. Repare-se no cercamento - habitual - empregado. / Foto de Marc Ferrez, c. 1885 / Arquivo Geral da Cidade do Rio de Janeiro.

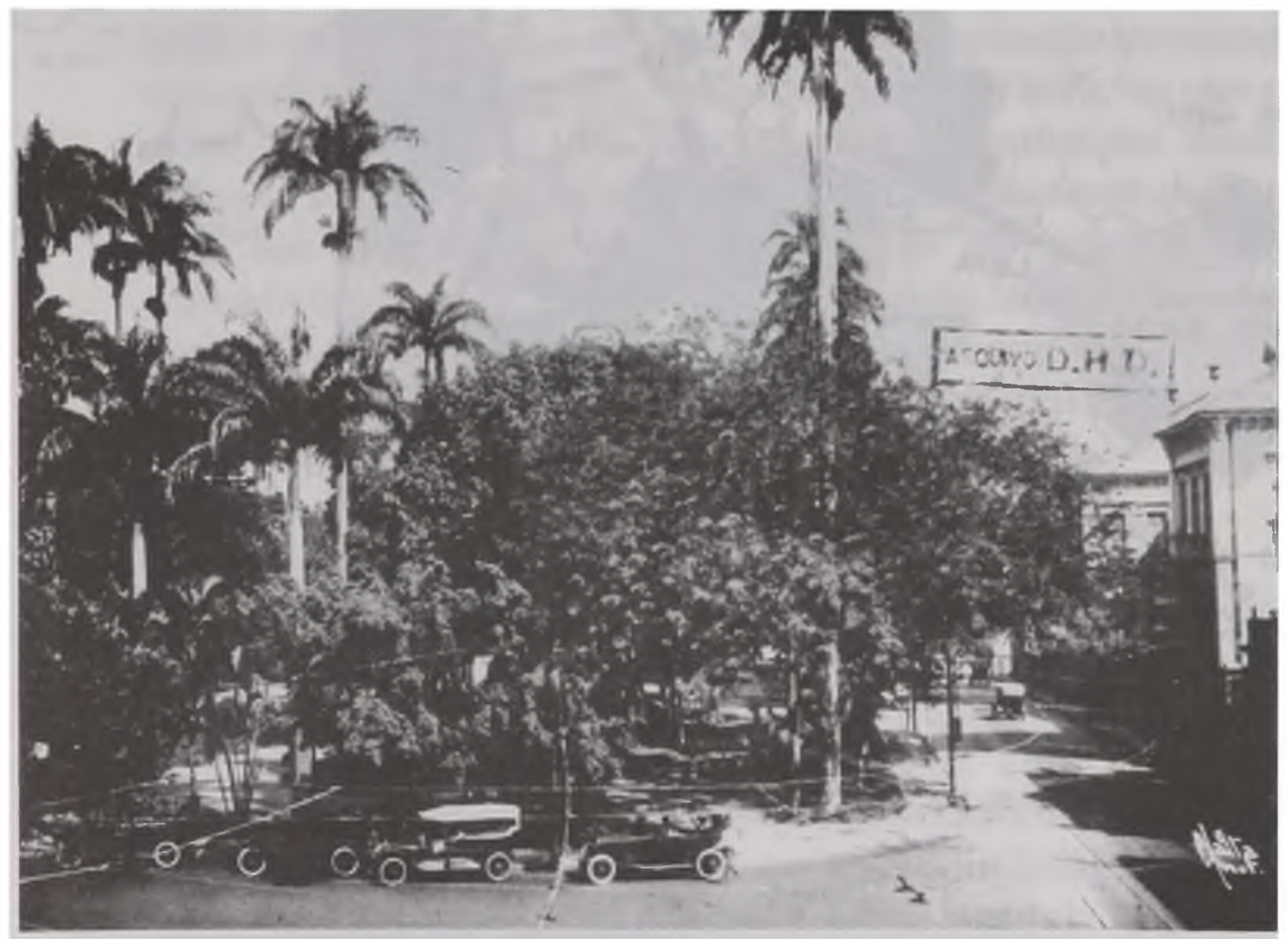

Figura 25 - Vistas do largo do Machado, já no nosso século, monstrando as mudanças registradas. No entorno adjacente / Foto de A. Malta, c. 1920 / Arquivo Geral da Cidade do Rio de Janeiro. 


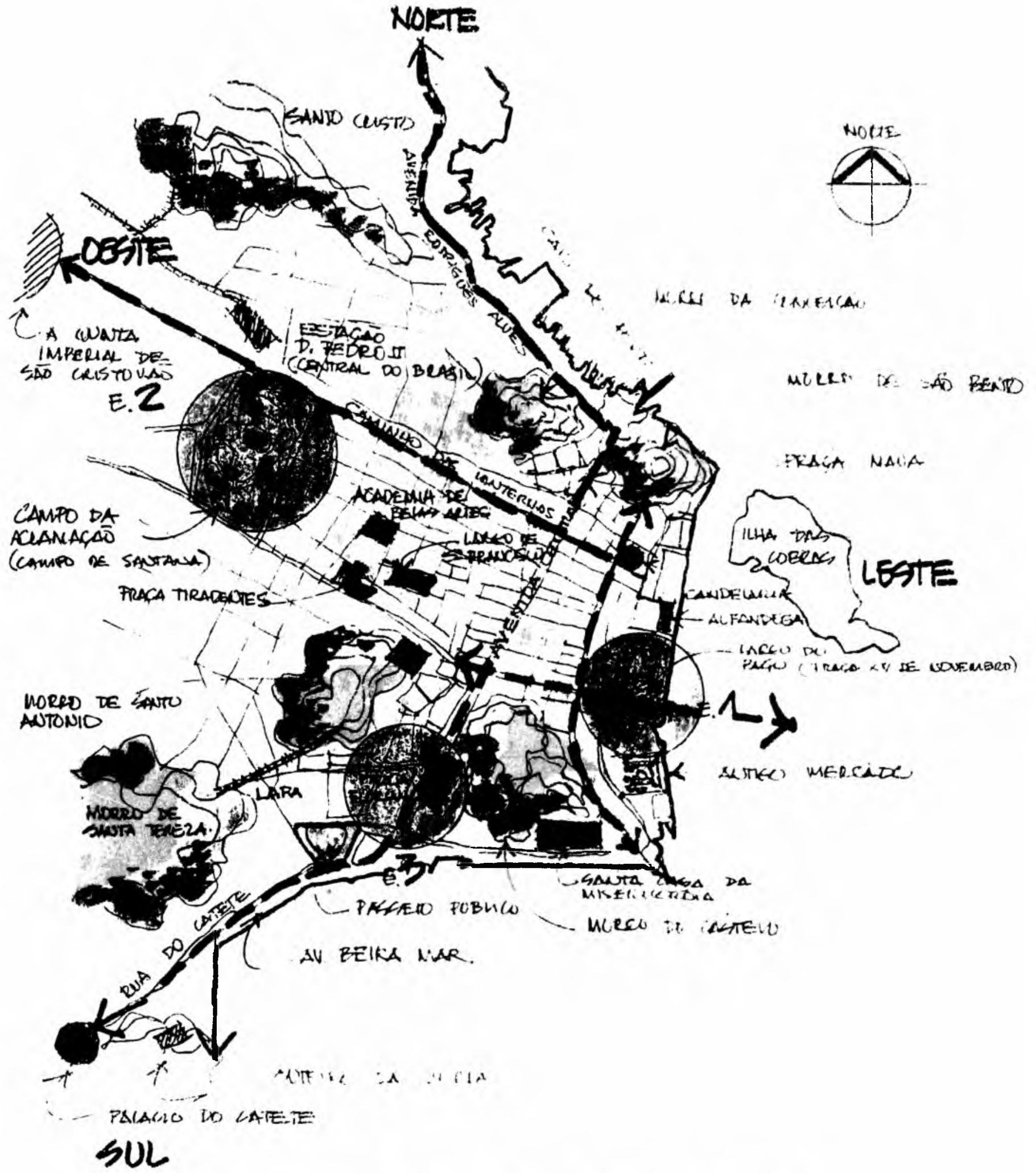

Figura 26- Os jardins como marcos profanos na configuração urbana do Rio de Janeiro, a partir do século 19 (desenho do autor). 


\section{CONCLUSÕES}

As discussões "proto-urbanísticas" que se suscitam na cidade do Rio de Janeiro do século 19, como vimos anteriormente, ajudam a entender a construção uma forma bem brasileira de pensar 0 espaço de uma metrópole, em termos de imagem, onde os espaços livres urbanosdesempenharam um papel importante na configuração espacial da cidade, preparando o clima adequado não só para a impressionante seqüência de intervenções urbanísticas no século 20 na cidade (começando pela reforma Pereira Passos, plano Agache, plano Sabóia, Doxiadis, etc.) como, também, para o aparecimento de figuras como Pereira Passos, Lúcio Costa, Affonso E. Reidy e o próprio Roberto Burle Marx, o que, por sinal, em momento algum da sua vida negou as raízes românticas que permearam a sua obra, e ao modernismo, de um modo geral.

Por outro lado, como mencionamos anteriormente, Glaziou inaugura a preocupação, em nosso meio, pelos aspectos ligados tanto à adoção de linhas de projeto para configuração do espaço livre urbano de uso público, quanto à gestão da obra, no que se refere à importância das condições de manutenção desses espaços, razão pela qual se debateu permanentemente durante toda sua estadia no Brasil, pela criação de uma estrutura administrativa e de conservação e projeto adequados, nos moldes franceses, de cuja preocupação iria se originar o Departamento de Parques e Jardins (atual Fundação Parques e Jardins), que recentemente cumpriu 100 anos de existência.

Na medida em que o Rio de Janeiro, devido à qualidade de metrópole e capital federal (até década de 60) somada a peculiar situação biogeográfica do seu assentamento físico, gerou desde século 19, sem dúvida, modelos de comportamento e arquétipos de agenciamento do espaço livre urbano, com freqüência adotados em outras cidades brasileiras, entendemos ser prioritário o desenvolvimento de pesquisas mais aprofundadas sobre esta temática, dado que por ela passa uma boa parte da história do espaço público brasileiro. 


\section{BIBLIOGRAFIA}

ABREU, Maurício de. Evolução urbana do Rio de Janeiro. Rio de Janeiro: Zahar, 1988.

ALPHAND, Adolphe. Les Promenades de Paris/Bois de Boulogne/Bois de Vicennes/Parcs/Squares/Boulevards. Paris: Rothschild, 1868.

ARESTIZÁBEL, Irna (curadora). A paisagem desenhada: $O$ Rio de Pereira Passos. Rio de Janeiro: Centro Cultural Banco do Brasil, 1994.

BENCHIMOL, Jaime Larry. Pereira Passos: Um Haussmann tropical/A renovação urbana da cidade do Rio de Janeiro no início do século 20. Rio de Janeiro: Biblioteca Carioca, 1990.

CANABRAVA, B. Eduardo. Atlas da evolução urbana da cidade do Rio de Janeiro/Ensaios/1565 - 1965. Rio de Janeiro: Instituto Histórico e Geográfico Brasileiro, 1965.

CENIQUEL, Mario. Paisagem urbana, cenário e percepção:A noção de memória como componente metodológica do projeto. In: Paisagem e Ambiente, São Paulo: FAUUSP, n. 7, 1995.

EWBANK, Thomas. A vida do Brasil ou diário de uma visita ao país do cacau e das palmeiras. Rio de Janeiro: Conquista, 1973. 2 v.

GARCIA, Rodolfo. Historia das explorações científicas. Rio de Janeiro: Instituto Geográfico e Histórico Brasileiro, 1927.

GIEDION, Siegfried. Espacio, tiempo y arquitectura: el futuro de una nueva tradicion. 5. ed., Madrid: Dossat, 1978.

LAURIE. Michael. An introduction to landscape architecture. USA: Pitman Publishing Limited, 1976.

LEITE, Maria Angela Faggin Pereira. A paisagem, a natureza e a natureza das atitudes do homem. In: Paisagem e Ambiente, São Paulo: FAUUSP, 1993, n. 4. 
MARIANO FILHO, José. O passeio público do Rio de Janeiro. Rio de Janeiro: (s.n.) 1943.

MOTTA, Flavio. Roberto Burle Marx e a nova visão da paisagem. São Paulo: Nobel, 1984.

REIS, José de Oliveira. Evolução urbanística do Rio de Janeiro. In: Revista Municipal de Engenharia. Rio de Janeiro, $1^{2}$ semestre, 1988.

. ORio de Janeiro e seus prefeitos, prefeitura da cidade do Rio de Janeiro. Rio de Janeiro, 1977.

SANTOS, Afonso Carlos Marques dos. Da colonização à Europa possível: as dimensões da contradição. In: Uma cidade em questão I: Grandjean de Montigny e o Rio de Janeiro. Rio de Janeiro: PUC/ FUNARTE/Fundação Roberto Marinho, 1979.

SANTOS, Paulo. O romantismo na arquitetura. In: Romantismo. Rio de Janeiro: Museu Nacional de BelasArtes, 1978. p. 137-152.

Quatro séculos de arquitetura. Rio de Janeiro: Fundação Educacional R. Pimentel, 1977.

SISSON, Rachel. Marcos históricos e configuraçōes espaciais, um estudo de caso: os centros do Rio de Janeiro. In: Arquitetura revista, FAU/UFRJ, n. 4, $2^{2}$ semestre 1986, p. 57-81.

THOMAS, Keith. Ohomem e omundo natural. São Paulo: Companhia das Letras, 1989 (orig. 1983).

\footnotetext{
"Este artigo originou-se, inicialmente, numa pesquisa desenvolvida na pós-graduação da FAUUSP em 1992, sob a orientação da professora dra. arquiteta Ana Maria Moraes Belluzo, complementando-se, posteriormente, em 1993, com a colaboração da arquiteta Vera Lucia R. Cardim, Gerente de Projetos da atual Fundação Parques e Jardins da Prefeitura da Cidade de Rio de Janeiro, porocasiâo da montagem da exposição intitulada "GLAZIOU EPARQUES E IARDINS: 100 ANOS DE PERMANENCIA NO PAISA GISMO CARIOCA", no Instituto dos Arquitetos do Brasil (IAB/RJ), comemorativa dos 100 anos de nomeação oficial de Auguste Marie François Glaziou, pelo Imperador D. Pedro II, como primeiro Diretor dos Jardins Públicos, Arborização e Florestas da cidade do Rio de Janeiro, em 01 de dezembro de 1893. No seu formato final, contamos também com a assessoria da arquiteta, pesquisadora e historiadora arquiteta Rachel Sisson.
} 